Research paper

\title{
Structural and mechanistic characterization of 6S RNA from the hyperthermophilic bacterium Aquifex aeolicus
}

\author{
Karen Köhler a, Elke Duchardt-Ferner ${ }^{\text {b, c }}$, Marcus Lechner ${ }^{\text {a }}$, Katrin Damm ${ }^{\text {a }}$, \\ Philipp G. Hoch ${ }^{\text {a }}$, Margarita Salas ${ }^{\mathrm{d}}$, Roland K. Hartmann ${ }^{\mathrm{a}, *}$ \\ a Philipps-Universität Marburg, Fachbereich Pharmazie, Institut für Pharmazeutische Chemie, Marbacher Weg 6, D-35037 Marburg, Germany \\ b Goethe-Universität Frankfurt am Main, Institut für Molekulare Biowissenschaften, Max-von-Laue-Straße 9, D-60438 Frankfurt am Main, Germany \\ ${ }^{\text {c } Z e n t r u m ~ f u ̈ r ~ b i o m a g n e t i s c h e ~ R e s o n a n z s p e k t r o s k o p i e ~(B M R Z), ~ G o e t h e-U n i v e r s i t a ̈ t ~ F r a n k f u r t ~ a m ~ M a i n, ~ M a x-v o n-L a u e-S t r . ~ 9, ~ D-60438 ~ F r a n k f u r t ~ a m ~ M a i n, ~}$ \\ Germany \\ ¿ Centro de Biología Molecular “Severo Ochoa” (CSIC-UAM), Universidad Autónoma de Madrid, Cantoblanco, 28049 Madrid, Spain
}

\section{A $R$ R T I C C L E I I N F}

\section{Article history:}

Received 1 December 2014

Accepted 3 March 2015

Available online 11 March 2015

\section{Keywords:}

Aquifex aeolicus

Hyperthermophilic bacterium

6S RNA

pRNA synthesis

Structure probing

Nuclear magnetic resonance spectroscopy (NMR)

\begin{abstract}
A B S T R A C T
Bacterial 6S RNAs competitively inhibit binding of RNA polymerase (RNAP) holoenzymes to DNA promoters, thereby globally regulating transcription. RNAP uses 6S RNA itself as a template to synthesize short transcripts, termed pRNAs (product RNAs). Longer pRNAs (approx. $\geq 10 \mathrm{nt}$ ) rearrange the 6S RNA structure and thereby disrupt the 6S RNA:RNAP complex, which enables the enzyme to resume transcription at DNA promoters. We studied 6S RNA of the hyperthermophilic bacterium Aquifex aeolicus, representing the thermodynamically most stable 6S RNA known so far. Applying structure probing and NMR, we show that the RNA adopts the canonical rod-shaped 6S RNA architecture with little structure formation in the central bulge $(\mathrm{CB})$ even at moderate temperatures $\left(\leq 37{ }^{\circ} \mathrm{C}\right)$. $6 \mathrm{~S}$ RNA:pRNA complex formation triggers an internal structure rearrangement of 6S RNA, i.e. formation of a so-called central bulge collapse $(C B C)$ helix. The persistence of several characteristic NMR imino proton resonances upon pRNA annealing demonstrates that defined helical segments on both sides of the $\mathrm{CB}$ are retained in the pRNA-bound state, thus representing a basic framework of the RNA's architecture. RNA-seq analyses revealed pRNA synthesis from 6S RNA in A. aeolicus, identifying 9 to $\sim 17$-mers as the major length species. A. aeolicus 6S RNA can also serve as a template for in vitro pRNA synthesis by RNAP from the mesophile Bacillus subtilis. Binding of a synthetic pRNA to A. aeolicus 6S RNA blocks formation of 6S RNA:RNAP complexes. Our findings indicate that A. aeolicus 6S RNA function in its hyperthermophilic host is mechanistically identical to that of other bacterial 6S RNAs. The use of artificial pRNA variants, designed to disrupt helix $\mathrm{P} 2$ from the $3^{\prime}-\mathrm{CB}$ instead of the $5^{\prime}-\mathrm{CB}$ but preventing formation of the $\mathrm{CBC}$ helix, indicated that the mechanism of pRNA-induced RNAP release has been evolutionarily optimized for transcriptional pRNA initiation in the $5^{\prime}-\mathrm{CB}$.
\end{abstract}

(C) 2015 Elsevier B.V. and Société Française de Biochimie et Biologie Moléculaire (SFBBM). All rights reserved.

\section{Introduction}

Bacterial 6S RNA is a small non-coding RNA that globally controls transcription by binding to housekeeping RNA polymerase

\footnotetext{
* Corresponding author.

E-mail addresses: karenkoehler2502@gmail.com (K. Köhler),duchardt@bio.unifrankfurt.de (E. Duchardt-Ferner), marcus.lechner@staff.uni-marburg.de (M. Lechner), katrin.damm@staff.uni-marburg.de (K. Damm), hoch@Staff.UniMarburg.DE (P.G. Hoch), msalas@cbm.csic.es (M. Salas), roland.hartmann@staff. uni-marburg.de (R.K. Hartmann).
}

(RNAP) holoenzymes [19] in competition with DNA promoters [6]. First described in Escherichia coli, 6S RNA has since then been predicted in all branches of the bacterial kingdom using structurebased annotation tools [1,21]. Bacterial 6S RNAs adopt a rod-shaped secondary structure with a central internal loop region (termed central bulge $(\mathrm{CB})$ ) mimicking a DNA promoter in its open conformation [1]. The transcriptional block mediated by 6S RNA is reversed in a process where RNAP synthesizes short de novo transcripts ( 10-20 nt), termed product RNAs (pRNAs), using 6S RNA as the template in an RNA-dependent RNA polymerization reaction. With progressing pRNA synthesis, an internal 6S RNA helix 
adjacent to the central bulge (helix P2, Fig. 1) is disrupted. Provided that pRNA transcripts are extended to a length that allows formation of a sufficiently stable duplex structure with 6S RNA, a novel intramolecular base pairing interaction forms in 6S RNA, experimentally validated for E. coli 6S RNA and Bacillus subtilis 6S-1 RNA $[3,12,17]$. The pRNA-induced structural rearrangement then leads to the dissociation of 6S RNA:RNAP complexes [3,16,20].

In an experimental RNomics approach, a 6S RNA homolog was also identified in the hyperthermophilic bacterium Aquifex aeolicus [22]. A. aeolicus 6S RNA, about $160 \mathrm{nt}$ in length (Fig. 1A), belongs to the shortest known 6S RNAs, which usually have sizes of about $200 \mathrm{nt}$. This correlates with the minimized genome size (1.6 Mbp) of $A$. aeolicus [7]. The secondary structure of $A$. aeolicus 6S RNA (Fig. 1A) is particularly stable: its rod-shaped minimal free energy (MFE) structure is calculated to have a free enthalpy $\Delta \mathrm{G}$ of $-96 \mathrm{kcal} /$ $\mathrm{mol}$ (E. coli 6S RNA [ $184 \mathrm{nt}] \Delta \mathrm{G}=-80 \mathrm{kcal} / \mathrm{mol}$; B. subtilis $6 \mathrm{~S}-1 \mathrm{RNA}$ [190 nt] $\Delta \mathrm{G}=-63 \mathrm{kcal} / \mathrm{mol}$ ) [16].

Up to now two different modes of the pRNA-induced rearrangement have been identified: (i) in E. coli 6S RNA, an extended hairpin is formed in the $3^{\prime}$-part of the central bulge $\left(3^{\prime}-\mathrm{CB}\right)$ by base pairing of $3^{\prime}$-CB residues with the $3^{\prime}$-strand of the disrupted helix P2 [12,17]; in the case of B. subtilis 6S-1 RNA, formation of a socalled central bulge collapse helix ( $\mathrm{CBC}$ helix) occurs by base pairing of residues in the $5^{\prime}-\mathrm{CB}$ with the $3^{\prime}$-strand of the disrupted helix P2 [3]. A. aeolicus 6S RNA was proposed to involve both modes of pRNA-induced reshaping, hairpin formation in the $3^{\prime}-\mathrm{CB}$ and formation of a CBC helix $[3,16]$.
In this work, we addressed the question whether the 6S RNA from the hyperthermophile $A$. aeolicus functions as a genuine $6 \mathrm{~S}$ RNA. Up to now, only 6S RNAs from mesophilic bacteria have been studied. We employed deep sequencing (RNA-seq) to identify pRNAs synthesized by $A$. aeolicus RNAP in vivo. In addition, the secondary structure of $A$. aeolicus 6S RNA in its ground state and in complex with pRNA was investigated by structure probing $\left(\mathrm{Pb}^{2+}-\right.$ induced hydrolysis, RNase T1 and V1 cleavage) and NMR spectroscopy. In vitro, we mechanistically studied $A$. aeolicus $6 \mathrm{~S}$ RNA as a substrate for the B. subtilis $\sigma^{\mathrm{A}}$-RNAP holoenzyme. Finally, we tested if artificial pRNAs that disrupt helix P2 from the $3^{\prime}$-side of the $C B$ are also capable of inducing a structural change that leads to the release of 6S RNA from RNAP, while preventing formation of the $\mathrm{CBC}$ helix.

\section{Results and discussion}

\subsection{Identification of pRNAs deriving from A. aeolicus $6 S$ RNA in vivo using dRNA-seq}

We applied RNA-seq to address the basic question whether A. aeolicus RNAP indeed utilizes 6S RNA in vivo to synthesize pRNAs - a hallmark feature of bacterial 6S RNAs. For this purpose, total RNA extracted from A. aeolicus cells grown at $85{ }^{\circ} \mathrm{C}$ to late exponential phase was analyzed for pRNA reads by 454 and Illumina sequencing (for details, see Materials and methods). In the 454 experiment, the same RNA preparation was split into two halves, one of which was additionally treated with Terminator ${ }^{\mathrm{TM}} 5^{\prime}-$
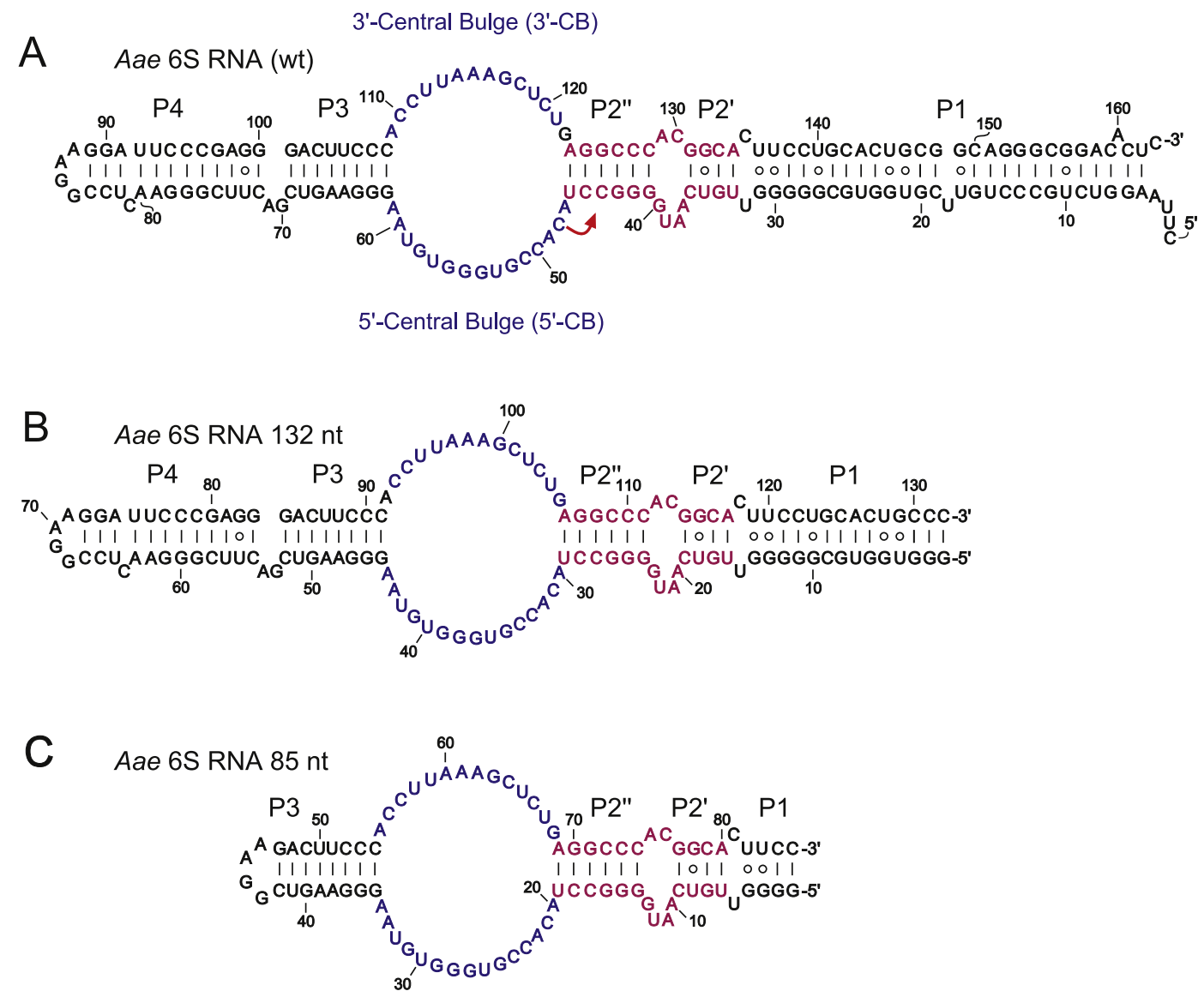

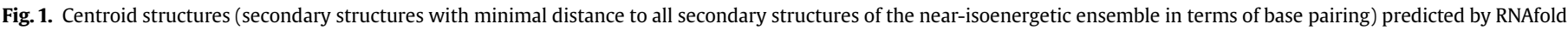

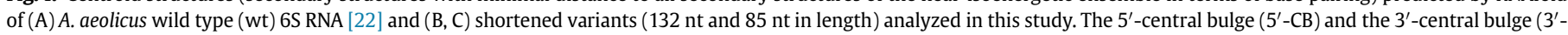
$\mathrm{CB}$ ) regions are marked in blue. The helices $\mathrm{P} 2^{\prime \prime}$ and $\mathrm{P} 2^{\prime}$ (purple) are disrupted during pRNA transcription. The pRNA initiation site is marked by the red arrow in panel A. 
Phosphate-Dependent Exonuclease (TEX) to enrich for primary transcripts. RNA preparations for Illumina sequencing were TEXtreated as well. As expected, pRNA reads were enriched after TEX treatment (Fig. 2A), consistent with their status as primary transcripts. In the 454 as well as in the Illumina experiment, all putative pRNA reads had the same $5^{\prime}$-terminus (Fig. 2A), supporting the notion that they were derived from genuine pRNAs rather than representing RNA fragments originating from other locations in the genome. The transcription start site (TSS) could be assigned to nucleotide C48 located in the $5^{\prime}-\mathrm{CB}$ of $A$. aeolicus 6S RNA (Fig. 1A), thus being at a similar location as in the well-studied $E$. coli and $B$. subtilis 6S RNA systems [16]. The cDNA read data suggest a pRNA length spectrum of up to $40 \mathrm{nt}$ (Fig. S1), thus almost as long as runoff transcripts ( $48 \mathrm{nt}$ according to Fig. 1A). The majority of reads represented pRNA 9 to $\sim 17$-mers (Fig. 2B). This does not exclude the possibility that pRNAs $<8 \mathrm{nt}$ are also synthesized in vivo, but those were not considered because their assignment was ambiguous (Fig. S1). The pRNA length spectrum in A. aeolicus is very similar to that observed for E. coli 6S RNA in vitro [12] and B. subtilis 6S-1 RNA in vitro and in vivo $[2,3]$. Gel shift experiments show that
pRNAs $\geq 10$ nt stably bind to the 132-nt 6S RNA (Fig. 1B) and persistently rearrange its structure (Fig. S2), which is consistent with the pRNA length spectrum observed in vivo (Fig. 2). It is thus reasonable to assume that even at growth temperatures of $85{ }^{\circ} \mathrm{C}$, pRNAs within this length range have sufficiently long dwell times (or sufficiently low $k_{\text {off }}$ values) to induce the structural rearrangement of A. aeolicus 6S RNA. In conclusion, our RNA-seq results suggest that the regulatory mechanism of 6S RNA-dependent pRNA transcription also takes place in a bacterium that thrives at temperatures around $85^{\circ} \mathrm{C}$.

\subsection{Secondary structure analysis via enzymatic and chemical probing}

To address the question if pRNA binding to A. aeolicus 6S RNA leads to a structural rearrangement as described for E. coli $6 \mathrm{~S}$ and B. subtilis 6S-1 RNA [16], enzymatic and chemical probing experiments were performed with two shortened variants of the A. aeolicus 6S RNA designed to render the RNA also amenable to structural analyses such as NMR measurements: a 132-nt variant,

\section{A}

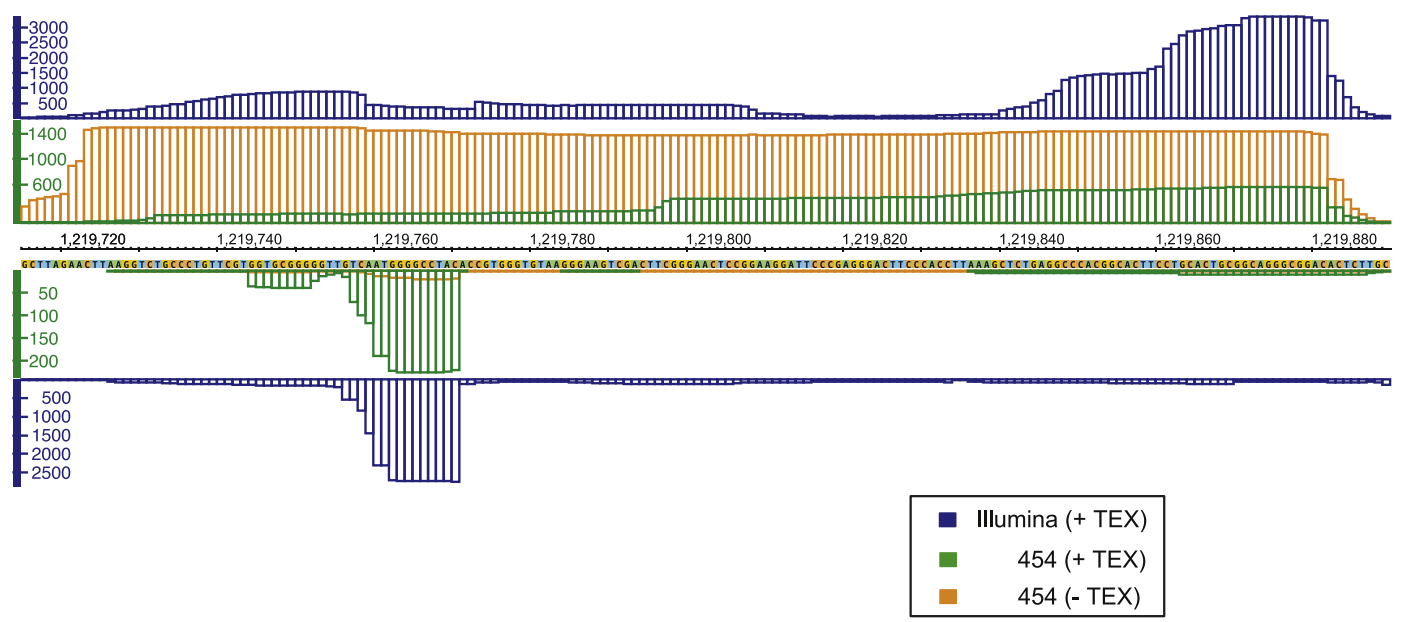

B

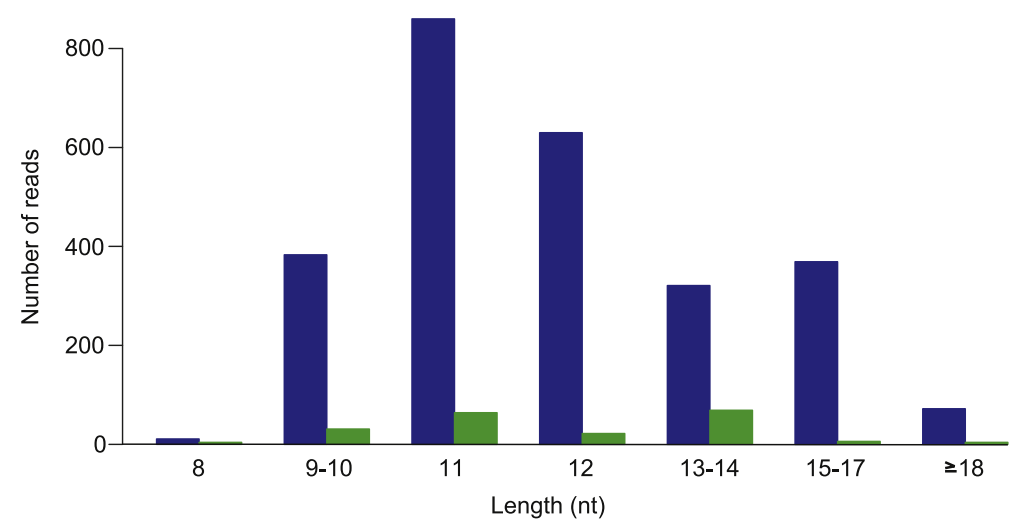

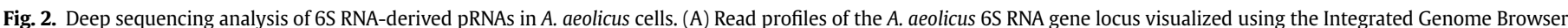

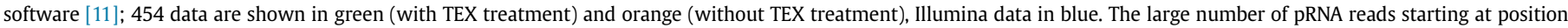

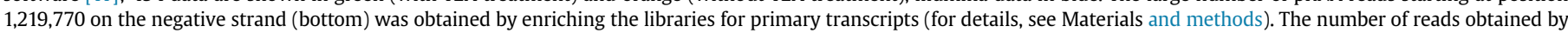

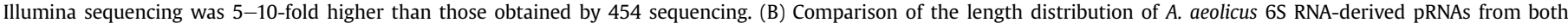

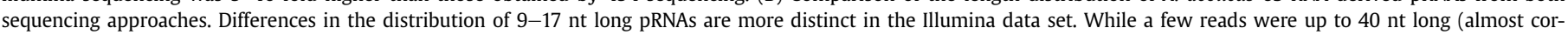
responding to runoff transcripts), those with a length of $\geq 18 \mathrm{nt}$ were combined in a single column for clarity. 
A

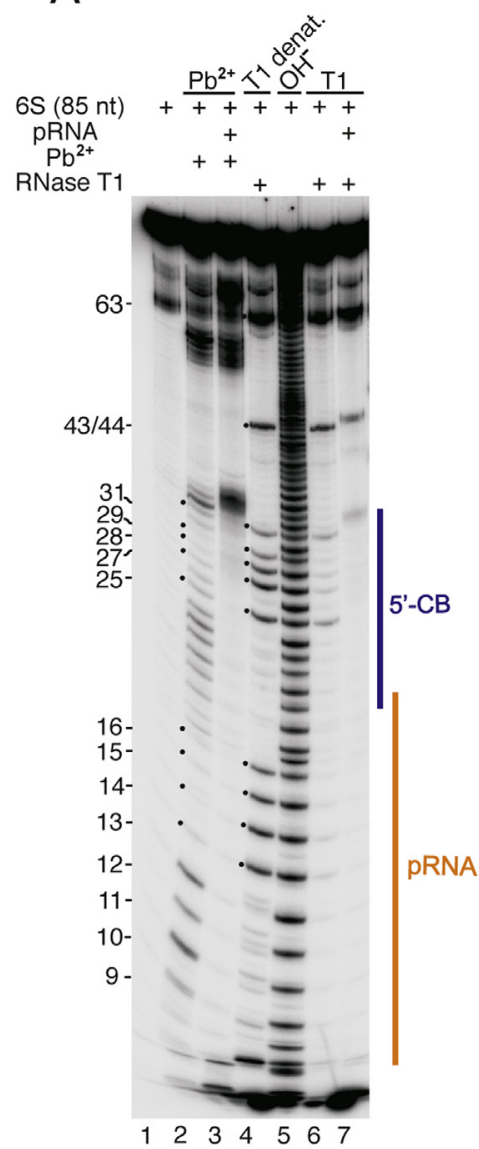

B
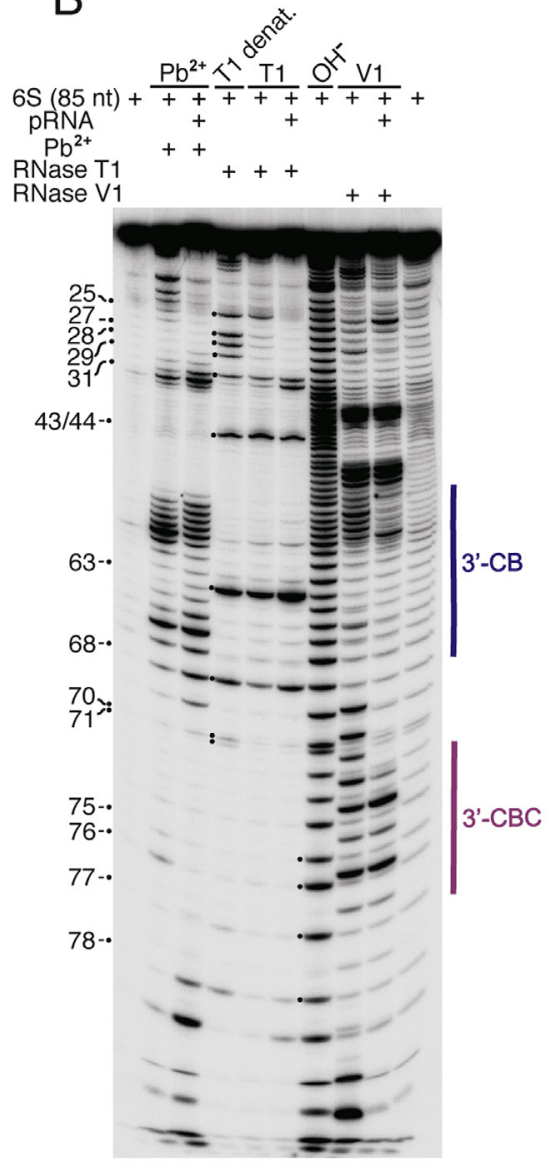

12234556788910

C
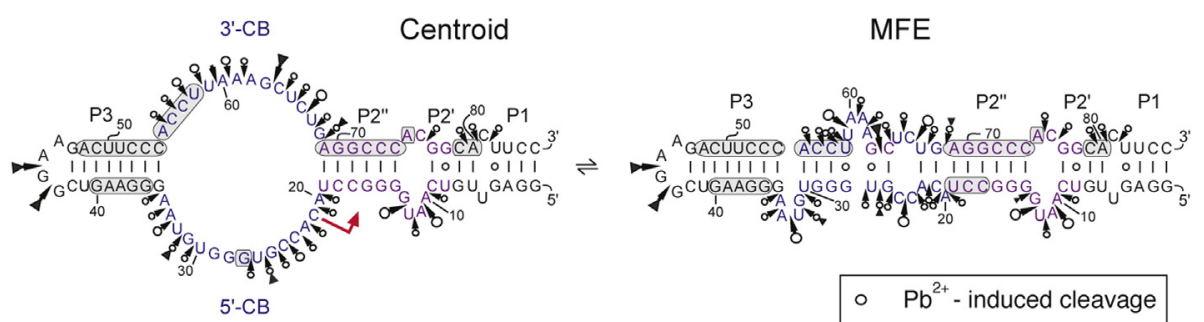

$\underbrace{5 '-C B}_{-}$

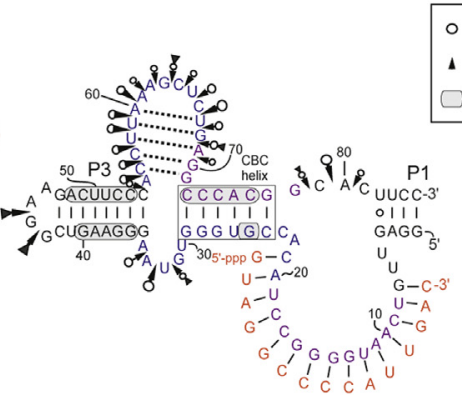

- $\mathrm{Pb}^{2+}$ - induced cleavage

- RNase T1 cleavage

RNase V1 cleavage

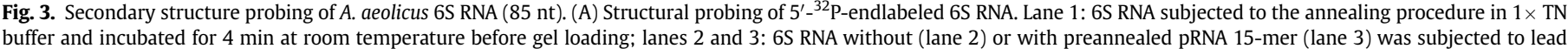

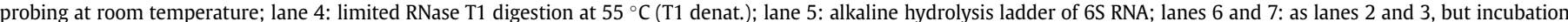

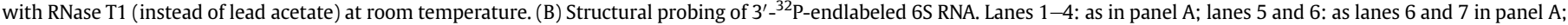

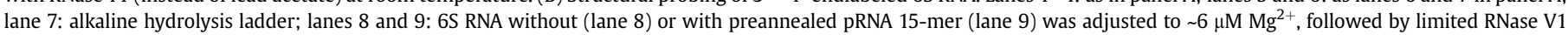

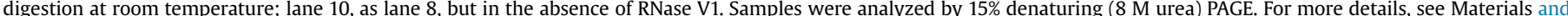

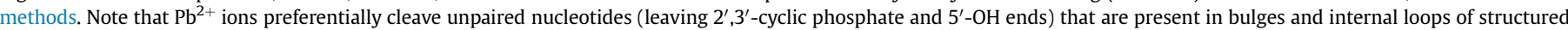

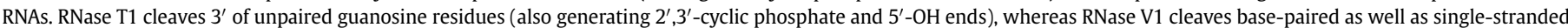

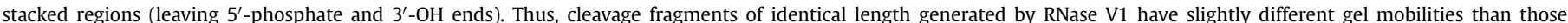

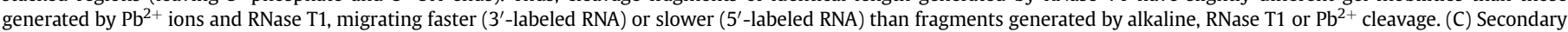

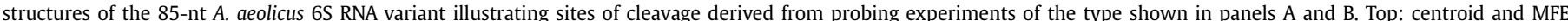

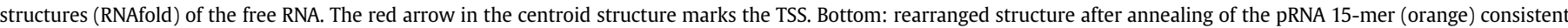

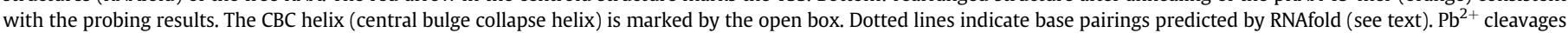

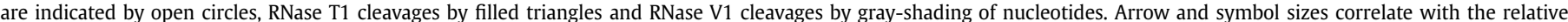
strength of the cleavage signals. Colored vertical lines at the gel images in panels A and B mark the correspondingly colored regions in the secondary structures. 

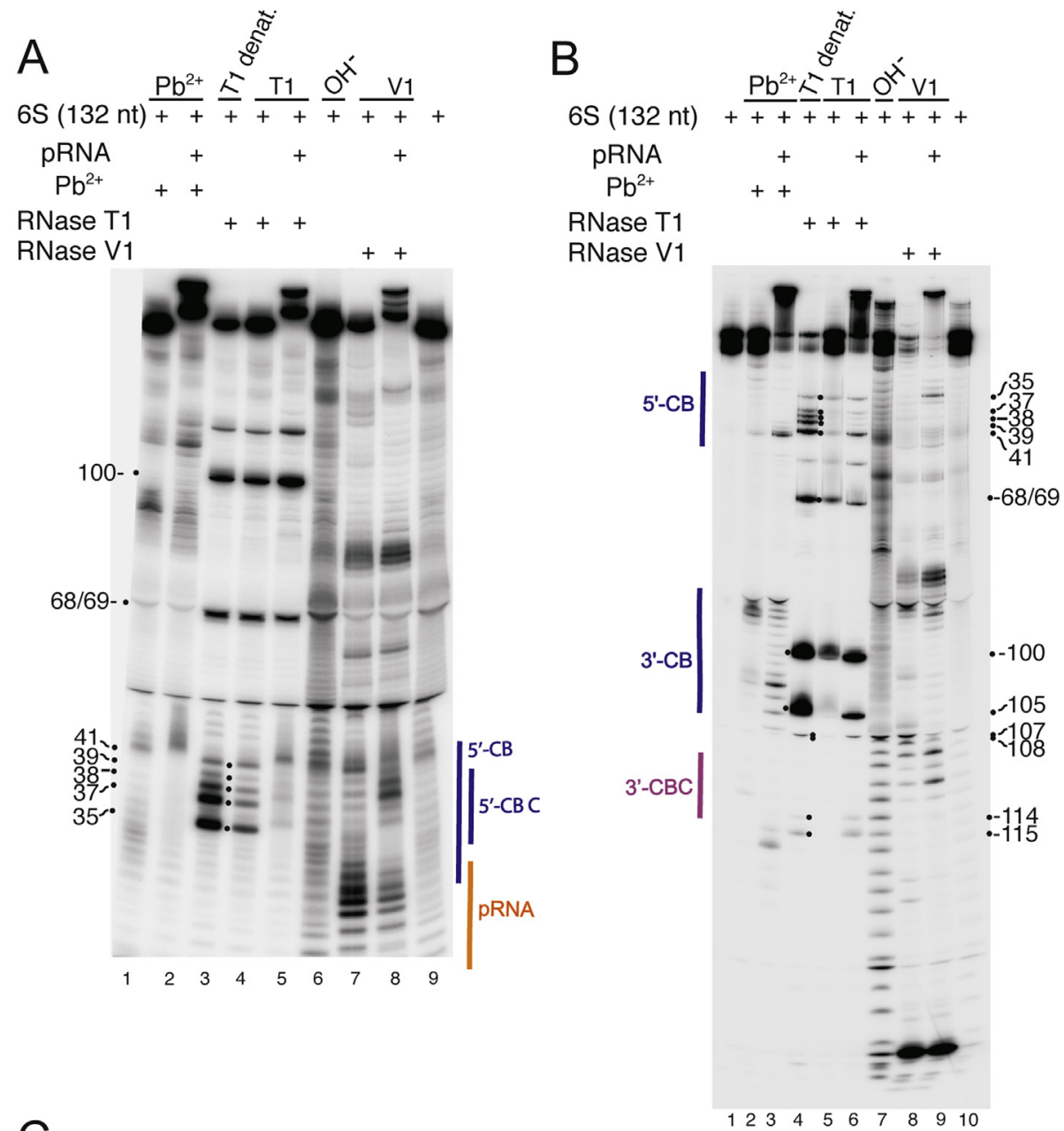

C

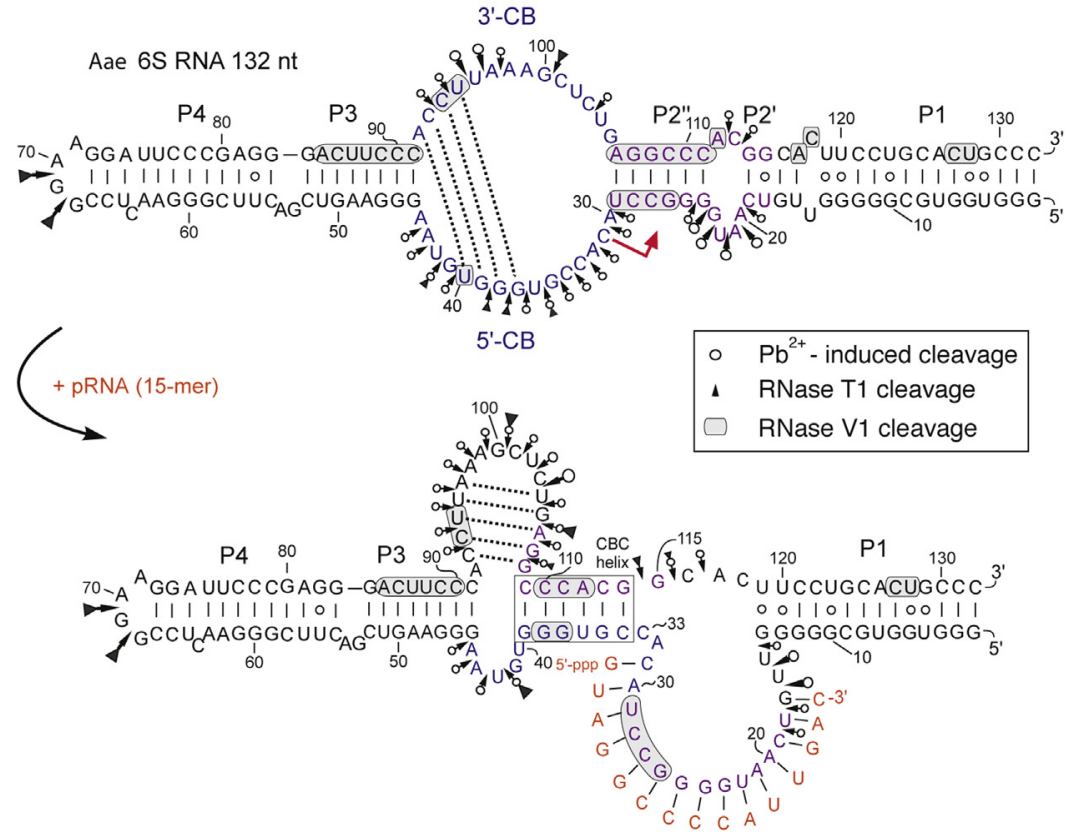

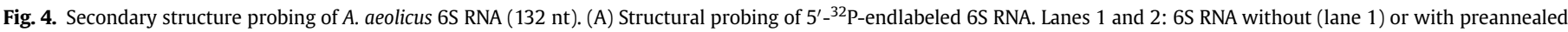

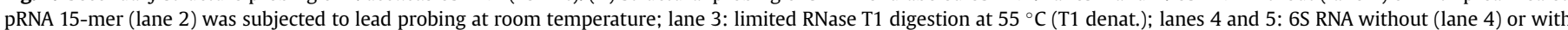

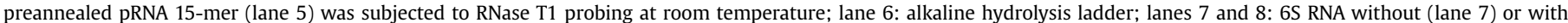

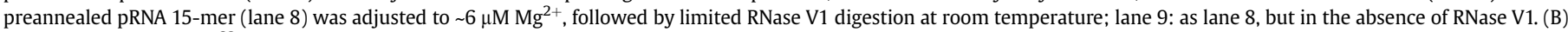

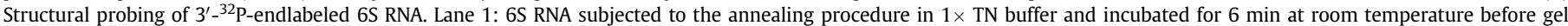

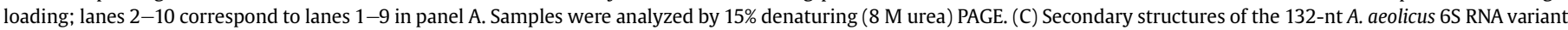

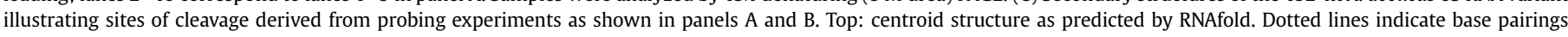



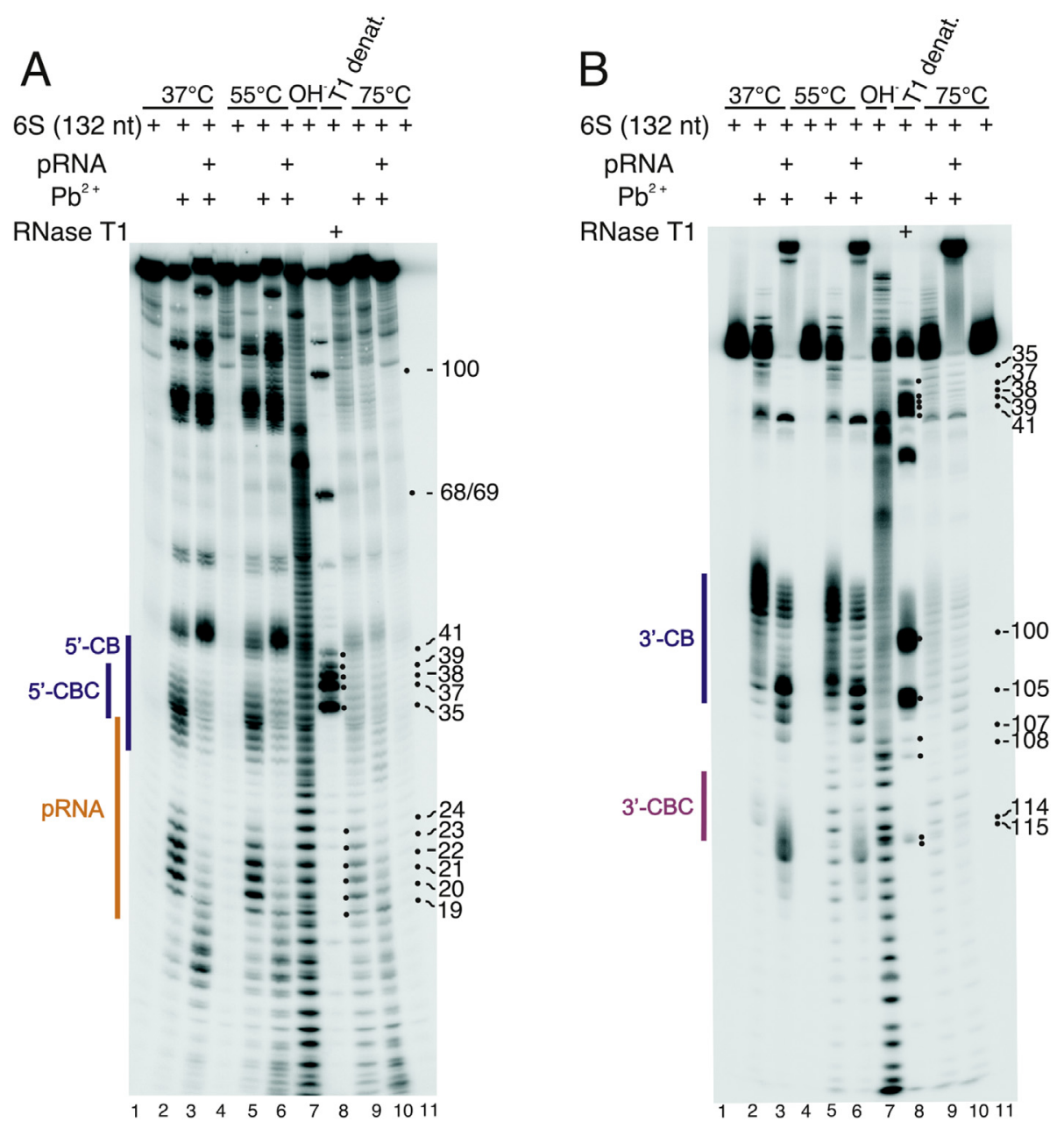

Fig. 5. Secondary structure probing of A. aeolicus $6 \mathrm{~S}$ RNA (132 nt) with Pb ${ }^{2+}$ ions at different temperatures. (A) Structural probing of 5'-32 P-endlabeled $6 \mathrm{~S}$ RNA. Lanes 1, 4 and 11 : $6 \mathrm{~S}$ RNA was subjected to the annealing procedure in $1 \times \mathrm{TN}$ buffer and incubated at $37^{\circ} \mathrm{C}$ for $4 \min$ (lane 1), $55^{\circ} \mathrm{C}$ for $1 \min$ (lane 4 ) and $75^{\circ} \mathrm{C}$ for $1 \mathrm{~min}$ (lane 11 ); lanes 2,5 and 9 : $6 \mathrm{~S}$ RNA was subjected to the annealing procedure in $1 \times \mathrm{TN}$ buffer before $\mathrm{Pb}^{2+}$ probing at $37^{\circ} \mathrm{C}$ for $4 \min$ (lane 2), $55^{\circ} \mathrm{C}$ for $1 \min$ (lane 5 ) and $75^{\circ} \mathrm{C}$ for 1 min (lane 9 ); lanes 3,6 and 10 : as lanes 2, 5 and 9, but with preannealing of the pRNA 15-mer; lane 7: alkaline hydrolysis ladder; lane 8: limited RNase T1 digestion at $55^{\circ} \mathrm{C}$ (T1 denat.). (B) Structural probing of $3^{\prime}$-32 P-endlabeled 6S RNA. For lane assignment, see panel A. Samples were analyzed by $15 \%$ denaturing (8 M urea) PAGE. For details, see Materials and methods. Colored vertical lines at the gel images mark the correspondingly colored regions in the secondary structures in Fig. $4 \mathrm{C}$.

slightly shortened at the terminal stem, and a 85-nt 6S RNA variant with more extensive truncations of the helical stems on both sides of the CB (Fig. 1B, C). Both RNAs are predicted by RNAfold [10] to fold as the native 163-nt RNA does in the corresponding regions (Fig. 1). We originally intended to also include the native 163-nt RNA in the probing experiments, but had difficulties to transcribe this RNA in vitro. We consider the 132-nt 6S RNA (lacking roughly $15 \mathrm{nt}$ from the $5^{\prime}$ - as well as from the $3^{\prime}$-end) to be a valid functional replacement of the 163-nt RNA, as inferred from the finding that a truncation of $20 \mathrm{nt}$ from the $5^{\prime}$ - as well as $3^{\prime}$-end of E. coli 6S RNA was essentially neutral to the RNA's function in vitro [14]. Likewise, even more extensively truncated variants of $B$. subtilis 6S-1 RNA still function as pRNA transcription templates in vitro (unpublished results). Finally, contact regions between E. coli $\sigma^{70}$ and 6S RNA inferred from affinity cleavage experiments were used to model $6 \mathrm{~S}$ RNA into crystal structures of bacterial RNAP holoenzymes [18].
According to this model, the terminal part of helix P1 corresponding to the truncation of the A. aeolicus 132-nt 6S RNA is likely located outside the contact area with RNAP [18]. As a mimic of a pRNA transcript, we used a synthetic isosequential RNA 15-mer providing sufficient duplex stability to form gel-resolvable complexes.

For the 85-nt variant, representative gel images are illustrated in Fig. $3 \mathrm{~A}$ and $\mathrm{B}$. Cleavage sites are summarized within the secondary structures shown in Fig. $3 \mathrm{C}$. At room temperature $\left(\sim 24^{\circ} \mathrm{C}\right)$, structure probing of the free 85-nt variant revealed pronounced accessibility to $\mathrm{Pb}^{2+}$-induced hydrolysis at positions $9-12, \sim 19-26$, to a minor extent at nt 27, at 30-34 (Fig. 3A, lane 2), as well as at positions 55-61, 64-68 and, to a minor extent, at nt 76 and 79-81 (Fig. 3B, lane 2). Cleavage by RNase T1 under native conditions (Fig. 3, panel A, lane 6, and panel B, lane 5 ) revealed accessibility of $\mathrm{G} 25, \mathrm{G} 31, \mathrm{G} 43 / 44, \mathrm{G} 63$, and $\mathrm{G} 68$, in line with the $\mathrm{Pb}^{2+}$ hydrolysis

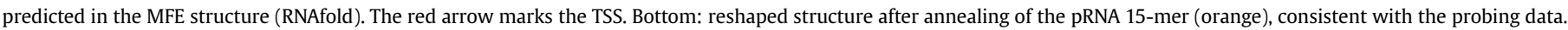

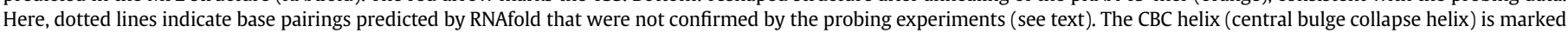

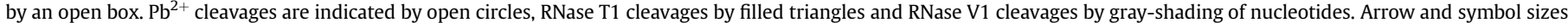

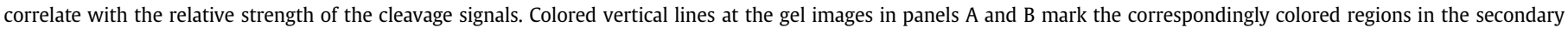
structures. 
data. RNase V1 cleavage of the $3^{\prime}-{ }^{32}$ P-labeled 85 -nt variant (Fig. 3B, lane 8) suggested helical structures in the region of approx. nt $36-40,48-51,55-58,69-75$ and $79 / 80$, in accordance with the centroid structure except for the stretch of nt 55-58 (Fig. 3C). In conclusion, hydrolysis patterns for the 85-nt variant are consistent with the MFE structure being in equilibrium with an open central bulge (centroid) structure (Fig. 3C) at room temperature. We infer that the open central bulge structure will dominate at higher temperatures closer to the natural growth temperature of A. aeolicus $\left(85^{\circ} \mathrm{C}\right)$.

Probing of the 85-nt 6S RNA variant after annealing of the pRNA 15-mer revealed the following changes in the hydrolysis pattern: the entire region from nt 8 to 29 as well as nt 76 became protected from $\mathrm{Pb}^{2+}$ cleavage, whereas nt 31-33, the region comprising nt 64-69, and nt 78-81 became more exposed to $\mathrm{Pb}^{2+}$-induced hydrolysis (Fig. 3A, B, lane 3 vs. 2). Key changes in the RNase T1 cleavage pattern include the protection of G25 to G29 (Fig. 3A, lane 7 vs. 6) and increased accessibilities of G63, G68 and G78 (Fig. 3B, lane 6 vs. 5). Annealing of the pRNA 15-mer reduced RNase V1 cleavage in the regions of nt 54-58 and 69-72, whereas cleavage at nt 25 was enhanced (Fig. 3B, lane 9 vs. 8). These pRNA-induced changes in the hydrolysis patterns are consistent with the structural rearrangement shown in Fig. 3C (bottom). A hallmark feature of the rearranged structure is the formation of the $\mathrm{CBC}$ helix (nt 24-29/72-77) between the $5^{\prime}$ - and $3^{\prime}$-CB. RNAfold analysis (Fig. S4B) also predicted C23 and G78 to base-pair as part of the CBC helix. As we saw some accessibility of nt 78 to $\mathrm{Pb}^{2+}$ and RNase T1 hydrolysis (e.g. Fig. 3B, lane 3), we propose some fraying of this terminal bp and have thus indicated it as unpaired in Fig. $3 \mathrm{C}$ (bottom).

Probing of the 132-nt variant of A. aeolicus 6S RNA at room temperature, with and without pRNA annealing, resulted in cleavage patterns consistent with those obtained for the 85-nt variant. Nucleotide 42, the region of nt 98-107 and nt 115/116 became more accessible to $\mathrm{Pb}^{2+}$ and RNase T1 cleavage (Fig. 4, panel A, lanes 1, 2, 4 and 5; panel B, lanes 2, 3, 5 and 6) upon pRNA annealing. Under the same conditions, cleavage by RNase V1 was enhanced at nt $37 / 38$ and $110-112$, consistent with formation of the CBC helix (Fig. 4, panel A, lanes 7 and 8; panel B, lanes 8 and 9). RNase V1 hydrolysis at nt 26-29 was weaker in the pRNA:6S RNA hybrid structure, reflecting the altered helical context of this sequence stretch in the ground state versus the pRNA hybrid structure.

$\mathrm{Pb}^{2+}$ probing of the 132-nt variant was additionally performed at $37{ }^{\circ} \mathrm{C}, 55{ }^{\circ} \mathrm{C}$ and $75{ }^{\circ} \mathrm{C}$ to obtain information regarding the temperature-dependent structural dynamics of the central bulge region of this thermostable 6S RNA (Fig. 5). At probing temperatures of $37^{\circ} \mathrm{C}$ and $55^{\circ} \mathrm{C}$, the $\mathrm{Pb}^{2+}$ cleavage pattern did not change significantly relative to room temperature. Little overall cleavage was observed at $75{ }^{\circ} \mathrm{C}$. The cleavage patterns obtained at $37{ }^{\circ} \mathrm{C}$ and $55^{\circ} \mathrm{C}$ confirmed the rearranged structure depicted in Fig. $4 \mathrm{C}$ (bottom): pRNA annealing caused enhanced $\mathrm{Pb}^{2+}$-induced hydrolysis around nt 15/16, 41-43,103-107, 115/116, whereas protection was observed at nt 19-24 (pRNA binding region) and approx. 30-37 (including the CBC helix) (Fig. 5, panels A and B, lanes 1-6). Noteworthy, retarded gel mobility of the full-length RNA (Fig. 5B, lanes 3, 6 and 10) indicates that the pRNA 15-mer remained stably attached to the 132-nt 6S RNA despite probing temperatures of up to $75^{\circ} \mathrm{C}$, sample heating to $95{ }^{\circ} \mathrm{C}$ in denaturing loading buffer and denaturing PAGE. This supports the notion that a tightly bound A. aeolicus pRNA 15-mer is able to induce the observed structural rearrangement even at extraordinarily high temperatures $\left(\sim 85^{\circ} \mathrm{C}\right)$.

For the free 85-nt and 132-nt RNAs, a hairpin in the $3^{\prime}-\mathrm{CB}$ is predicted to form at room temperature (Figs. S3A and S4A) but not at higher temperatures. When the pRNA binding site was blocked for intramolecular base pairing in RNAfold predictions, this hairpin was predicted to be present even at temperatures of up to $75^{\circ} \mathrm{C}$ (Figs. S3B and S4B; indicated by dotted lines in Figs. 3C and 4C). In this hairpin, nt 56-60/67-71 of the 85-nt 6S RNA variant would be base-paired. However, nt 56-60 were accessible to $\mathrm{Pb}^{2+}$ hydrolysis in the free and pRNA hybrid structure, and G68 even showed enhanced RNase T1 susceptibility after pRNA annealing (Fig. 3B, lane 6 vs. 5). For the 132-nt variant, nt 93-97/104-108 should be base-paired when the hairpin is formed. However, nt 105 was even more accessible to $\mathrm{Pb}^{2+}$ and RNase $\mathrm{T} 1$ hydrolysis upon pRNA annealing (Fig. 4C). These findings argue against formation of this hairpin in the $3^{\prime}$-CB region of the reshaped structure, in contrast to the RNAfold predictions (Fig. S3B and S4B) and previous suggestions [3].

We conclude that the pRNA-induced structural rearrangement of $A$. aeolicus 6S RNA involves formation of the CBC helix, in keeping with RNAfold calculations predicting the $\mathrm{CBC}$ helix at all temperatures of up to $95^{\circ} \mathrm{C}$ (Figs. S3B and S4B).

\subsection{Secondary structure analysis via NMR}

We further performed NMR measurements to analyze the structure of 6S RNA and 6S RNA:pRNA complexes by an independent approach and in more detail, including the potential to gain information about possible tertiary interactions. In the ${ }^{1} \mathrm{H},{ }^{15} \mathrm{~N}$ HSQC spectrum (Fig. 6 A, top) of the free 132-nt 6S RNA variant we detected imino groups with characteristic ${ }^{1} \mathrm{H}$ and ${ }^{15} \mathrm{~N}$ resonance frequencies, demonstrating the presence of four stable Watson-Crick A:U base pairs, twelve stable Watson-Crick G:C base pairs and four stable non-canonical G:U base pairs. The distance information from a ${ }^{1} \mathrm{H},{ }_{1}^{1} \mathrm{H}-\mathrm{NOESY}$ spectrum of the 6S RNA 132-nt variant (Fig. 6A, bottom) together with the ${ }^{1} \mathrm{H},{ }^{15} \mathrm{~N}-\mathrm{HSQC}$ spectrum of the truncated 85-nt 6S RNA variant in its free state (Fig. S5) allowed the assignment of all detected $A: U$ and all G:U base pairs as well as six out of the twelve G:C base pairs (Fig. 6B). Assignment of the remaining $G$ imino resonances is likely hampered by their small spectral dispersion leading to cross peaks overlapping with the diagonal in the ${ }^{1} \mathrm{H},{ }_{1}^{1} \mathrm{H}$ NOESY spectrum. The predicted MFE structure of the 132 -nt $6 \mathrm{~S}$ RNA at $37{ }^{\circ} \mathrm{C}$ implies some base-pairing between the $5^{\prime}$ - and $3^{\prime}$-portion of the central bulge, including two A:U and two G:U pairs (dotted lines in Fig. 6B, top). The absence of additional stable $U$ imino resonances both in the region typical for A:U Watson-Crick as well as for U:G base pairs suggests that basepairing in the $C B$ is not stable and therefore escapes detection by NMR spectroscopy. The same pertains to the predicted base pairs G13:U120, G14:U119 and U16:A117. The region between base pairs G24:C111 to U29:A106, which is predicted to be base-paired in the free 6S RNA (Fig. 6B) while its $5^{\prime}$-strand is hybridized to the pRNA in the rearranged state, likely provides the identity of at least 5 of the 6 unassigned $\mathrm{G}$ imino resonances in the free structure.

To detect pRNA-induced changes in 6S RNA structure with maximum resolution and specificity, ${ }^{15} \mathrm{~N}$ isotope-labeled 6S RNA (132 nt) was hybridized to an all-LNA analog of the pRNA 15-mer to maximize duplex stability (Fig. 6A, top). In addition, a ${ }^{1} \mathrm{H},{ }^{1} \mathrm{H}$ NOESY spectrum was obtained for unlabeled 132-nt 6S RNA:pRNA complexes (Fig. 6A, bottom). Comparison with the spectrum of the free 132-nt 6S RNA revealed that structural changes upon pRNA hybridization are confined to the central bulge region and nucleotides in its immediate vicinity. Accordingly, the U18:G115 base pair vanishes in agreement with local unwinding of helices $\mathrm{P}^{\prime}$ and $\mathrm{P2}{ }^{\prime \prime}$ upon pRNA hybridization (Fig. 6). The assigned stem region between G5 and G10 is still present in the 6S RNA:pRNA duplex, demonstrating that the terminal 6S RNA stem (P1) is not unwound upon annealing of a pRNA 15-mer. In line with the probing data (Figs. 3 and 4), formation of a hairpin within the $3^{\prime}$-central bulge 

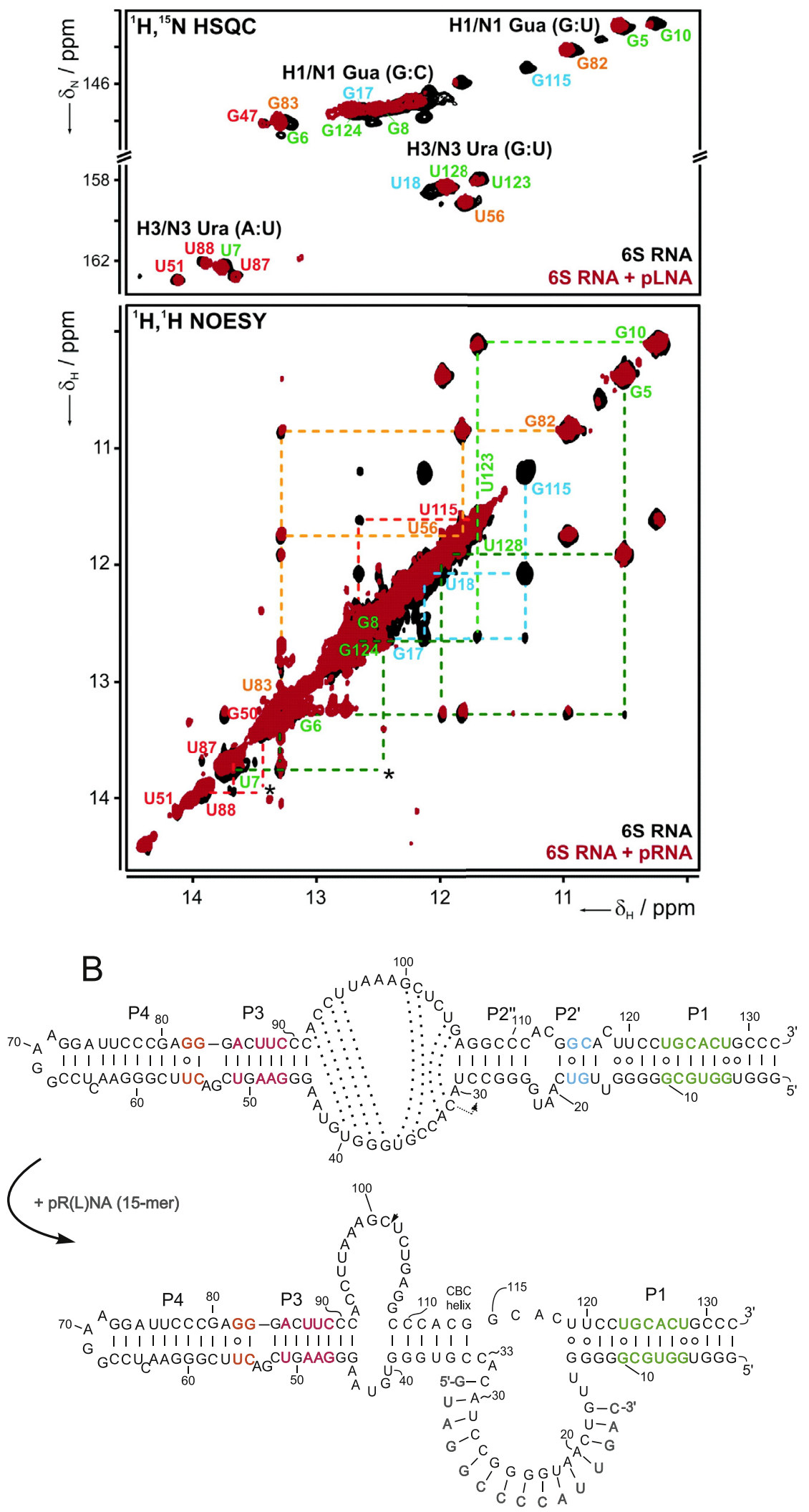

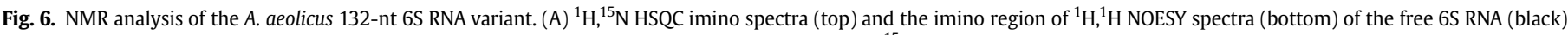

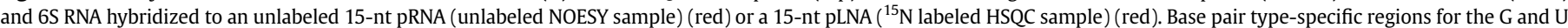

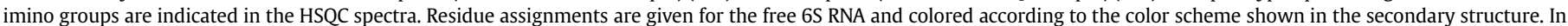

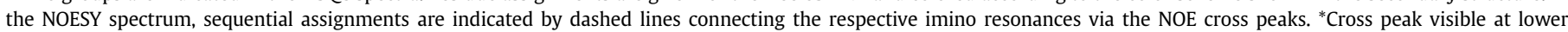

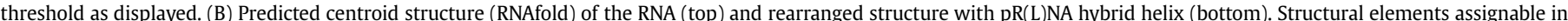

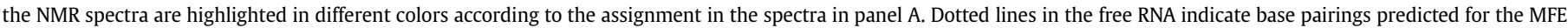
structure (RNAfold) which are not supported by the NMR data. 
A
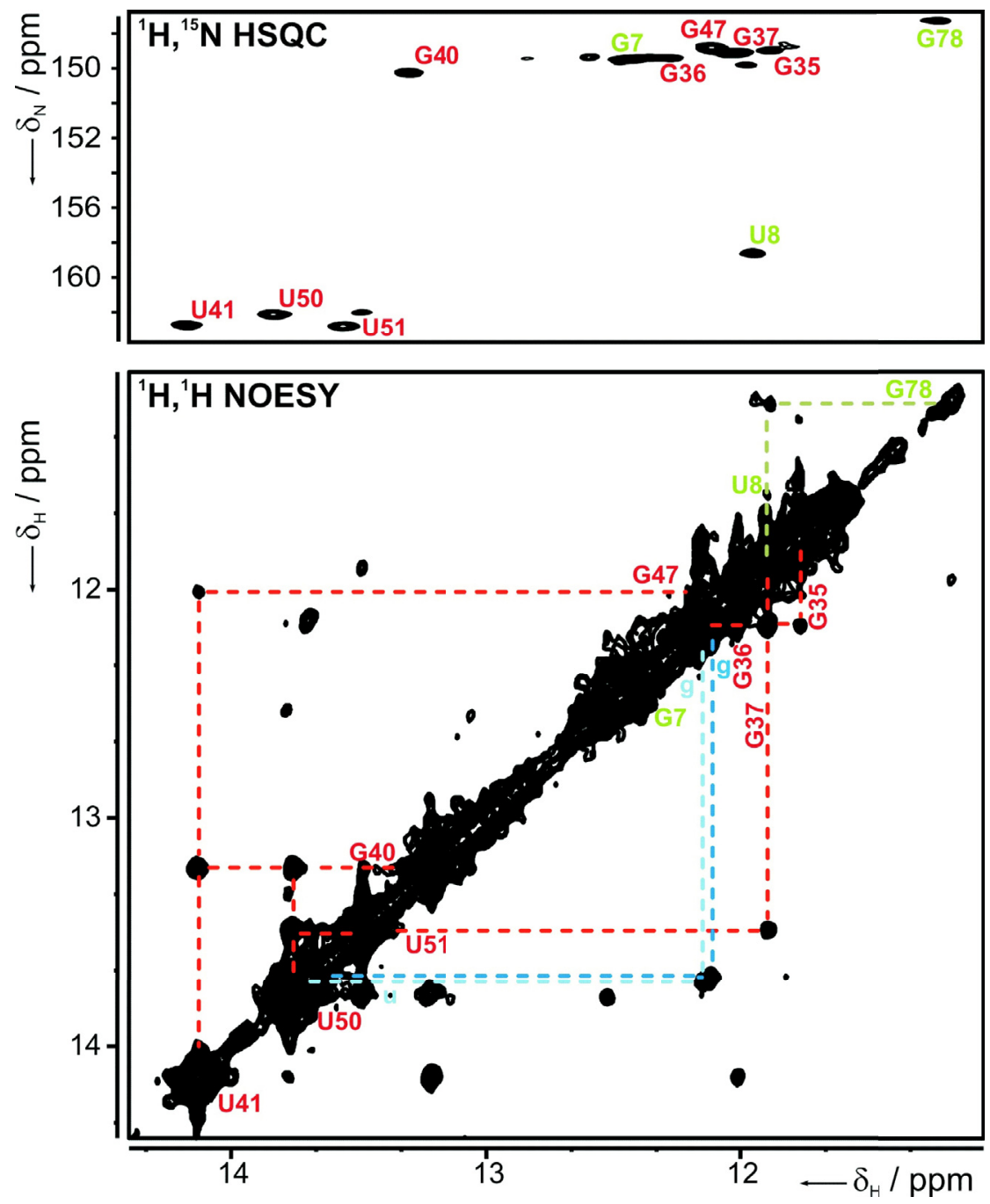

B

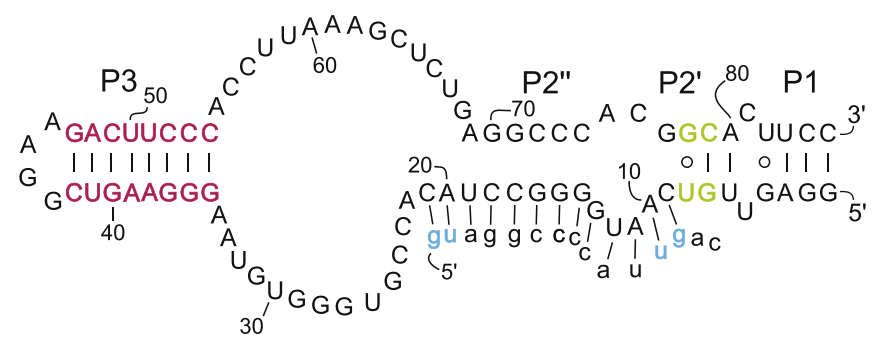

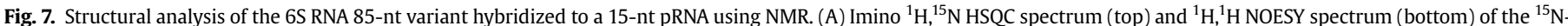

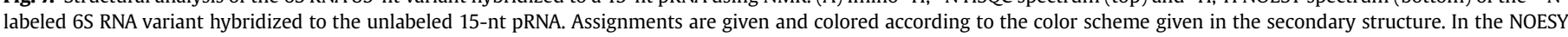

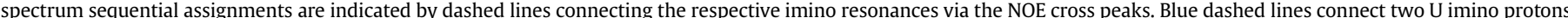

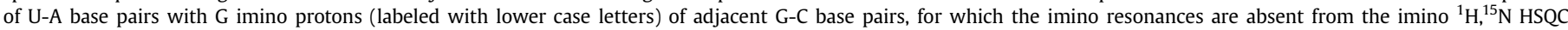

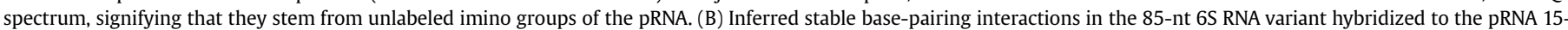

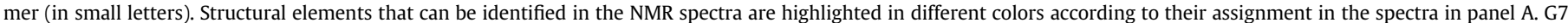
was identified due to its chemical shifts and NOE connectivities in the free RNA (data not shown).

region of 6S RNA after the pRNA-induced structural rearrangement (dotted lines in Fig. 4C, bottom), as predicted in silico (Figs. S3B and S4B; [3]), is also not supported by the NMR data. The stem of this hairpin, which would be composed of three G-C and two A-U base pairs, should give rise to additional Watson-Crick type $U$ imino resonances, which were, however, not detected in the ${ }^{1} \mathrm{H},{ }^{15} \mathrm{~N}$ HSQC spectrum. This does not exclude that hairpin formation occurs transiently involving conformational transitions between a structured and an unstructured state. In this case, one would at best expect broadened imino resonances, as hydrogen bonding needs to 
A

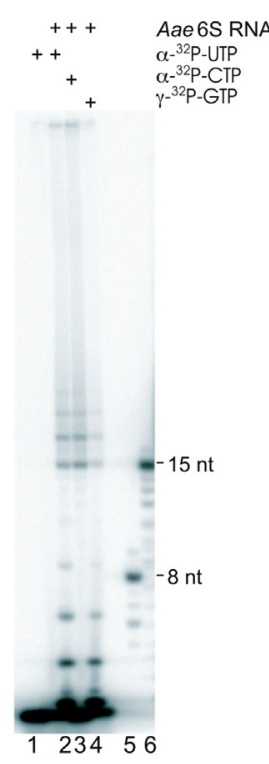

B
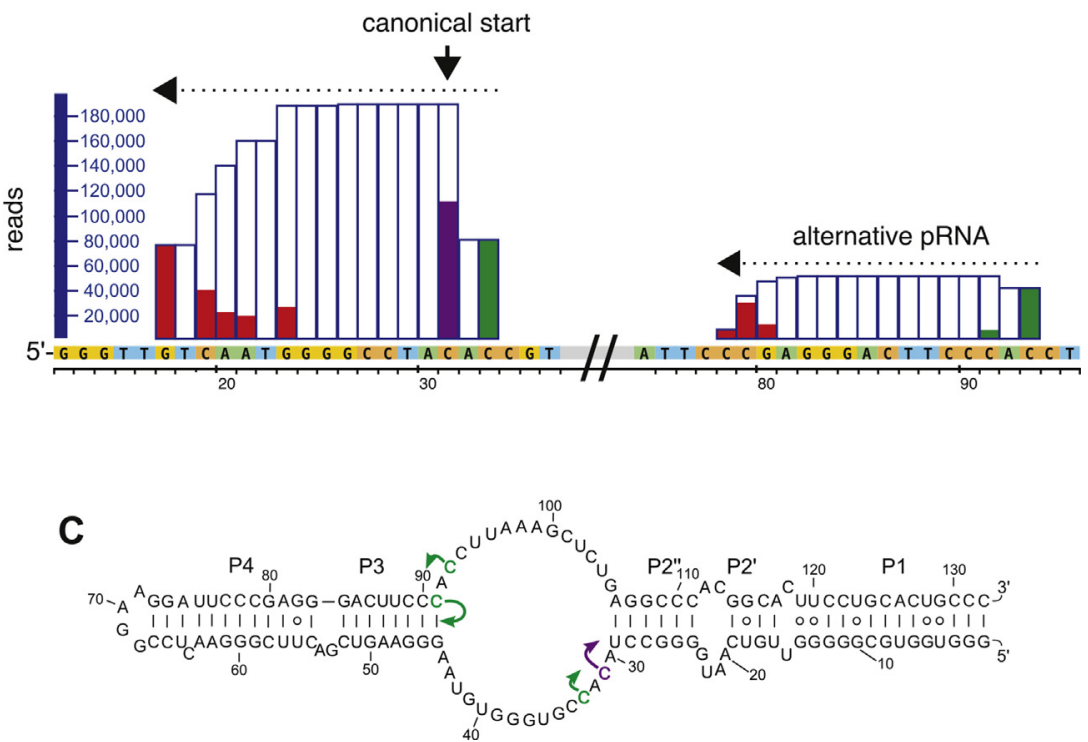

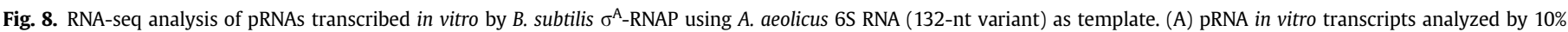

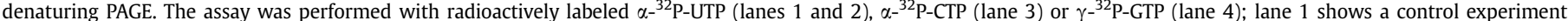

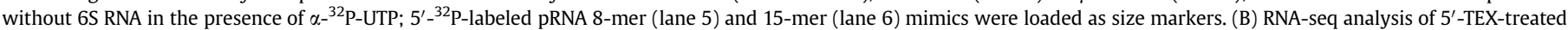

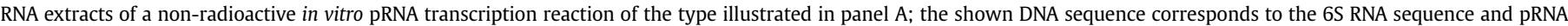

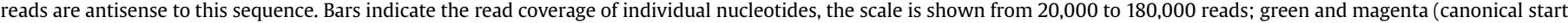

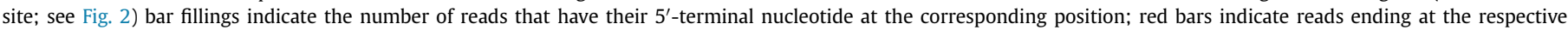

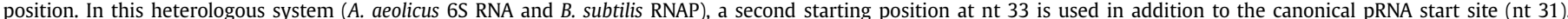

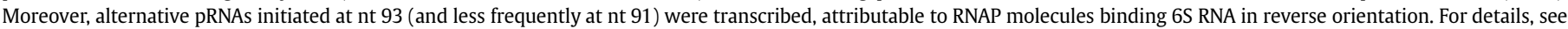

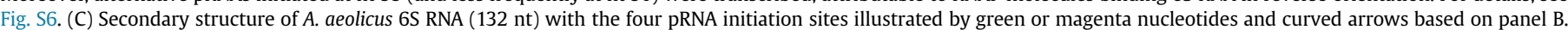

be sufficiently protected from solvent exchange to remain detectable by NMR. The complete absence of corresponding imino resonances suggests that the hairpin is very volatile or not formed at all, which is consistent with its low predicted stability $(-2.8 \mathrm{kcal} / \mathrm{mol}$ for the MFE structure predicted by RNAfold using the default parameters).

Compared to free 6S RNA, about five unassigned G imino resonances of Watson-Crick base pairs disappear or decrease in intensity in the 6S RNA:pRNA duplex structure. One explanation for the disappearance of three of these signals is that they belong to $G$ residues in the region between $\mathrm{A} 106$ and G114, which are predicted to be base-paired to residues C19, C27 and C28 in free 6S RNA (Fig. 6B). In 6S RNA:pRNA/pLNA 15-mer complexes, residues 17 to 31 of 6S RNA pair with pRNA/pLNA, which concomitantly displaces the stretch of nt A106 to A117, of which nt 109 to 114 become engaged in forming the $\mathrm{CBC}$ helix, as inferred from the probing experiments (see Fig. 4C). As the CBC helix was not directly observed by NMR, we conclude that it is relatively unstable, at least under NMR measurement conditions. In summary, our NMR analyses have identified stem regions on both sides of the central bulge that are particularly stable (Fig. $6 \mathrm{~B}$, colored $\mathrm{nt}$ ), thus providing a structural framework for the rod-shaped A. aeolicus 6S RNA architecture at elevated temperatures. Simultaneously, formation of the $\mathrm{CBC}$ helix appears as a more dynamic or fine-tuning mechanistic element in the pRNA-induced rearrangement that leads to dissociation of 6S RNA:RNAP complexes. Nevertheless, formation of the $\mathrm{CBC}$ helix may well influence the pRNA length pattern and the kinetics and directionality of the structural rearrangement.

The structural changes induced by pRNA binding were also investigated using the smaller 85-nt 6S RNA to obtain improved spectral resolution. Even in this truncated 6S RNA variant, the relatively short terminal helix persists in the 6S RNA:pRNA hybrid, as inferred from the presence of G7, U8 and G78 imino resonances
(Fig. 7A). This may indicate stabilization of the terminal helix through stacking interactions with the pRNA:6S RNA helix. The large extent of signal overlap in helix P3 (G47 to U51) flanking the central bulge in free 6S RNA and 6S RNA:pRNA duplexes supports the notion that this arm of the 6S RNA is not affected by the pRNAinduced rearrangement (Fig. S5). The resonances of G35 and G36 at the junction between helix P3 and the central bulge become apparent only after hybridization with the pRNA (Fig. S5), suggesting a stabilizing effect of the pRNA:6S RNA helix possibly through stacking interactions with P3. However, no further NOE cross peaks to any coaxially stacking residues could be observed in the NOESY spectrum, possibly due to signal overlap in the G:C region.

\subsection{In vitro transcription of $p R N A s$ from A. aeolicus $6 S$ RNA}

After we had proven by RNA-seq analysis that pRNA transcription takes place in $A$. aeolicus cells, we wanted to investigate whether our 85-nt and 132-nt 6S RNA variants serve as templates for in vitro transcription. Since the homologous A. aeolicus RNAP has not been available we fell back on the well examined RNA polymerase of $B$. subtilis. This decision was also favored by the observation that pRNAs synthesized from A. aeolicus 6S RNA and B. subtilis 6S-1 RNA are both initiated with G residues (Fig. 2; [2]). No significant pRNA synthesis by $B$. subtilis $\sigma^{A}$-RNAP was seen with the 85-nt variant as template (data not shown), likely because this truncated 6S RNA bound to $\sigma^{\mathrm{A}}$-RNAP with low affinity and specificity. In contrast, pRNA transcripts were obtained with the 132-nt 6S RNA variant, either synthesized in the presence of $\alpha-{ }^{32} \mathrm{P}-\mathrm{UTP}$, $\alpha-{ }^{32} \mathrm{P}-\mathrm{CTP}$ and $\gamma-{ }^{32} \mathrm{P}-\mathrm{GTP}$ for detection. Under the applied assay conditions ( $200 \mu \mathrm{M}$ of each NTPs, $1 \mu \mathrm{M} \sigma^{\mathrm{A}}$-RNAP, $1 \mu \mathrm{M}$ 132-nt $6 \mathrm{~S}$ RNA), predominantly 15 to 17 -meric pRNAs but also shorter ones $(<8 \mathrm{nt})$ were observed (Fig. 8A, lanes 2-4). This experiment 
demonstrated that the mesophilic $B$. subtilis $\sigma^{\mathrm{A}}$-RNAP is able to utilize A. aeolicus 6S RNA (the most stable 6S RNA known) as a template for pRNA transcription at $37{ }^{\circ} \mathrm{C}$, suggesting that 6S RNAtemplated pRNA transcription is mechanistically very similar at least in a subset of mesophilic and hyperthermophilic bacteria. We next examined if these pRNAs synthesized by a heterologous mesophilic RNAP are identical to those synthesized by A. aeolicus RNAP in vivo (Fig. 2). This was addressed by RNA-seq using RNA prepared from non-radioactive in vitro transcriptions of the type shown in Fig. 8A.

\subsection{RNA-seq analysis after in vitro pRNA transcription}

B. subtilis $\sigma^{\mathrm{A}}$-RNAP generated two types of pRNA transcripts with different starting regions when acting on A. aeolicus 6S RNA (132 nt) as template. First, reads for pRNA transcripts complementary to nt 15-34 of 6S RNA were identified in the RNA-seq data. These reads represent pRNAs initiated at the canonical start site (C31), thus corresponding to those synthesized in vivo in A. aeolicus (Fig. 2). C31 was predominantly used by B. subtilis $\sigma^{\mathrm{A}}$-RNAP in vitro, as most reads had their $5^{\prime}$-terminus at this position. The other reads mapped to pRNAs initiated at C33 (Fig. 8B, C), thus also encoding pRNAs with a $5^{\prime}$-terminal $G$ residue. GTP is most efficiently incorporated by $B$. subtilis $\sigma^{\mathrm{A}}$-RNAP as the starting nucleotide $[2,5]$.

The finding of varying pRNA initiation sites indicates that the enzyme acts somewhat less specifically on the heterologous $6 \mathrm{~S}$ RNA. On the other hand, the length distribution of pRNA reads was quite similar to that observed for the in vivo RNA-seq data (Fig. 2), indicating that 6S RNA binding to RNAP and pRNA transcription are very similar in the mesophile $B$. subtilis and the hyperthermophile A. aeolicus. A second smaller peak (9-fold less reads) of pRNA reads could be assigned to the opposite $3^{\prime}-\mathrm{CB}$ region (Fig. $8 \mathrm{C}$ ). These alternative pRNAs were predominantly initiated at $\mathrm{C} 93$, but also at C91, again yielding pRNAs with a favorable 5 -terminal $\mathrm{G}$ residue. This second type of pRNA transcripts indicates that A. aeolicus $6 \mathrm{~S}$ RNA was bound by the $B$. subtilis RNAP in two orientations, resulting in pRNA transcripts initiated at opposite sites in the central bulge. This phenomenon has also been observed to occur in vivo in various bacteria, such as Helicobacter pylori [13], E. coli, B. subtilis or Listeria monocytogenes [21].

\subsection{Analysis of $6 S$ RNA:RNAP complexation}

In view of the finding that $B$. subtilis $\sigma^{\mathrm{A}}$-RNAP is able to utilize A. aeolicus 6S RNA as a template for pRNA transcription (Fig. 8), we further analyzed the formation of A. aeolicus 6S RNA:B. subtilis RNAP complexes and their disruption upon pRNA annealing. B. subtilis 6S-1 RNA representing the homologous system was used as control. $\sigma^{\mathrm{A}}$-RNAP indeed formed gel-resolvable complexes with both 6S RNAs (Fig. 9A, lane 5, and Fig. 9B, lane 14). Preannealing of the specific pRNA 15-mer to A. aeolicus 6S RNA and an equivalent pRNA 14-mer to B. subtilis 6S-1 RNA decreased specific complex formation (Fig. 9A, lane 6, and Fig. 9B, lane 15). We next addressed the question whether disruption of the helical structure adjacent to the central bulge (magenta nucleotides in Fig. 9C and D) by a pRNA invading the structure from the $3^{\prime}$-CB side may also shift the 6S RNA structure and thus impair complex formation with RNAP. Since in this case formation of the CBC helix (Fig. 4C) is prevented, the experiment was supposed to shed light on the role of the $\mathrm{CBC}$ helix in the 6S RNA rearrangement and RNAP release process. The 3'-CB pRNAs were designed to form duplexes with roughly equal thermodynamic stability as the respective duplexes formed with the canonical 5'-CB pRNAs (Fig. 9C and D). The A. aeolicus 6S RNAspecific $3^{\prime}-\mathrm{CB}$ pRNA changed gel mobility to the same extent and quantitatively as the canonical 5'-CB pRNA (Fig. 9A, lanes 2 and 3), whereas the $3^{\prime}-\mathrm{CB}$ pRNA designed for B. subtilis 6S-1 RNA bound inefficiently under the tested conditions and the complex with $6 \mathrm{~S}-1$ RNA migrated differently from the one annealed to the $5^{\prime}-\mathrm{CB}$ pRNA (Fig. 9B, lanes 11 and 12). Accordingly, disruption of the 6S-1 RNA:RNAP complex by the $3^{\prime}-\mathrm{CB}$ pRNA was barely detectable (Fig. 9B, lane 16 vs. 14). In the case of $A$. aeolicus 6S RNA, annealing of the $3^{\prime}-\mathrm{CB}$ pRNA appeared to even increase complex formation with RNAP, but in a non-specific manner as inferred from a smear above the specific 6S RNA:RNAP complex (Fig. 9A, lane 7). A control pRNA with the same sequence as the A. aeolicus 6S RNA-specific 3'$\mathrm{CB}$ pRNA but reversed polarity neither affected complex formation of $\sigma^{A}$-RNAP with $A$. aeolicus $6 \mathrm{~S}$ RNA nor with the homologous B. subtilis 6S-1 RNA (Fig. 9A, lane 8, and Fig. 9B, lane 17). We conclude that such artificial $3^{\prime}-\mathrm{CB}$ pRNAs can more (A. aeolicus $6 \mathrm{~S}$ RNA) or less (B. subtilis 6S-1 RNA) efficiently induce conformational changes in 6S RNA structure. Although the mobility shift of 6S RNA was the same with the $5^{\prime}$ - and $3^{\prime}-\mathrm{CB}$ pRNAs in the case of $A$. aeolicus 6S RNA, RNAP binding was not blocked after $3^{\prime}$-CB pRNA annealing but rather non-specific gel-resolvable complexes with RNAP were observed. This finding suggests that strand specificity of the pRNA duplex and/or formation of the CBC helix (prevented in case of the $3^{\prime}$-CB pRNA) are crucial for the RNAP release process. Formation of the $\mathrm{CBC}$ helix also masks the single-stranded region in the $5^{\prime}-\mathrm{CB}$ that is considered to be a "-10"-like contact region of RNAP [12]. Thus, the pRNA-induced RNAP release mechanism has been evolutionarily optimized for pRNAs whose synthesis is initiated in the $5^{\prime}-\mathrm{CB}$.

\subsection{Conclusions}

In summary, we were able to define the solution secondary structure of A. aeolicus 6S RNA in its ground state as well as after the pRNA-induced structural rearrangement using structure probing and NMR. The free RNA adopts the canonical rod-shaped architecture with little structure formation in the central bulge already at moderate temperatures. We demonstrated that pRNA invasion into the 6S RNA structure leads to formation of a new central bulge collapse helix, similar to what has been observed for B. subtilis 6S-1 RNA [3]. The computationally predicted formation of an additional hairpin in the $3^{\prime}-\mathrm{CB}$ upon pRNA binding (Figs. S3 and S4) was neither indicated by the probing data nor by the NMR measurements. Such hairpin formation is a hallmark of the pRNA-induced rearrangement in a subgroup of proteobacterial 6S RNAs including the one from E. coli [16].

We further demonstrated that A. aeolicus 6S RNA mechanistically behaves as a genuine 6S RNA, serving as a template for pRNA synthesis in vivo. Remarkably, $\sigma^{\mathrm{A}}$-RNAP of the mesophile $B$. subtilis is able to use this 6S RNA of hyperthermophilic origin as a template for pRNA transcription. Binding of pRNA to A. aeolicus 6S RNA blocks formation of 6S RNA:RNAP complexes, a typical feature of $6 S$ RNAs. The RNA-seq analysis using total RNA from A. aeolicus identified pRNAs predominantly 9 to $\sim 17 \mathrm{nt}$ in length, but also longer ones that almost correspond to runoff transcripts ( 40 -mers). We showed for a pRNA 15-mer that it forms an extraordinarily stable duplex with A. aeolicus 6S RNA which even resists the denaturing PAGE treatment (Fig. 5). All these findings suggest that $A$. aeolicus 6S RNA mechanistically functions in the same way as other bacterial 6S RNAs in its A. aeolicus host at temperatures around $85^{\circ} \mathrm{C}$.

We finally tested if disruption of helix P2 by sequestering its $3^{\prime}-$ strand in a duplex with an artificial $3^{\prime}-\mathrm{CB}$ pRNA may trigger dissociation form RNAP as well. However, canonical pRNAs with their $5^{\prime}$-end mapping to the $5^{\prime}-\mathrm{CB}\left(5^{\prime}-\mathrm{CB}\right.$ pRNAs) are more efficient and specific than $3^{\prime}-\mathrm{CB}$ pRNAs with respect to the structural rearrangement and RNAP release process. Thus, the mechanism of pRNA-induced disruption of 6S RNA:RNAP complexes has been 
A

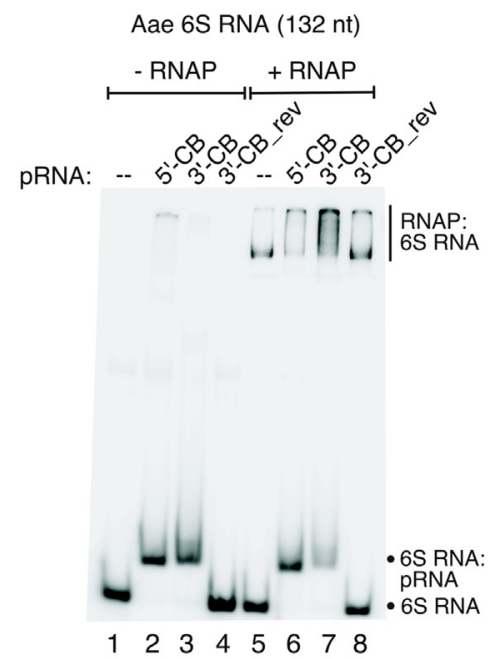

B

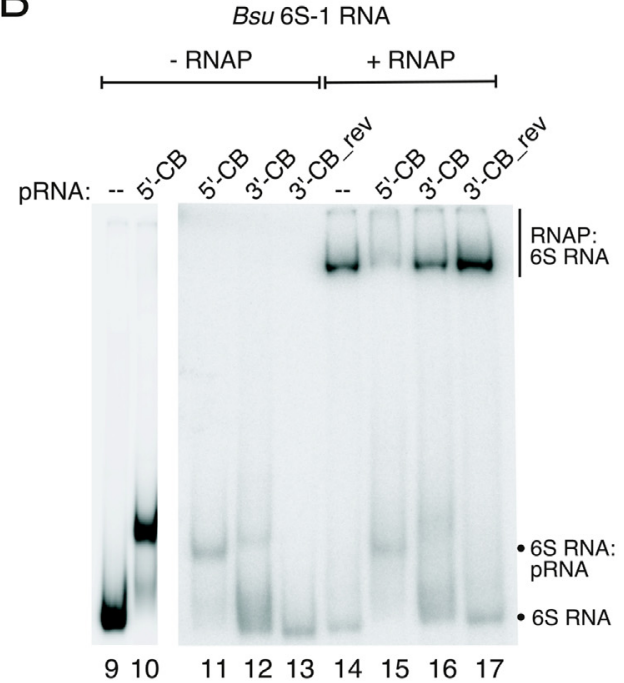

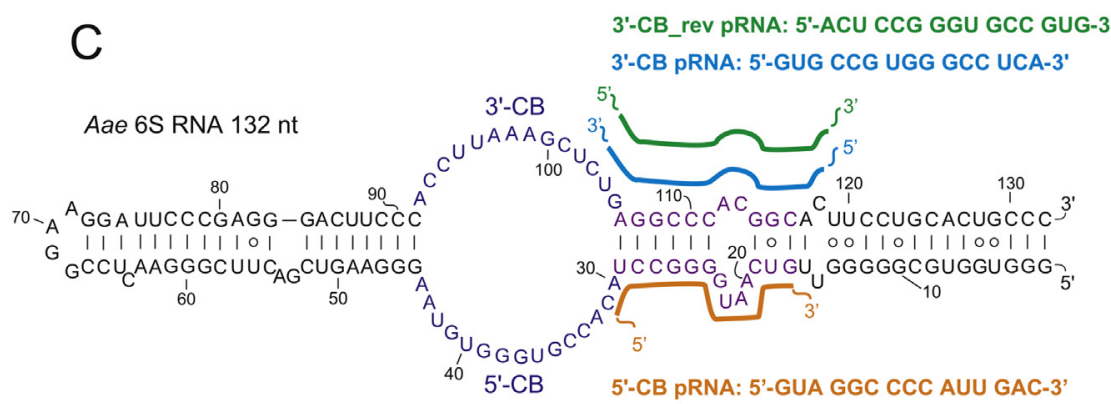

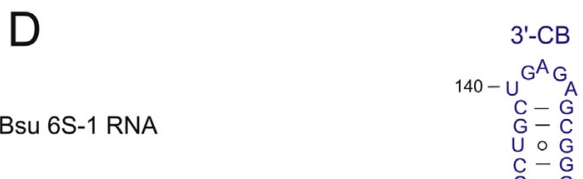

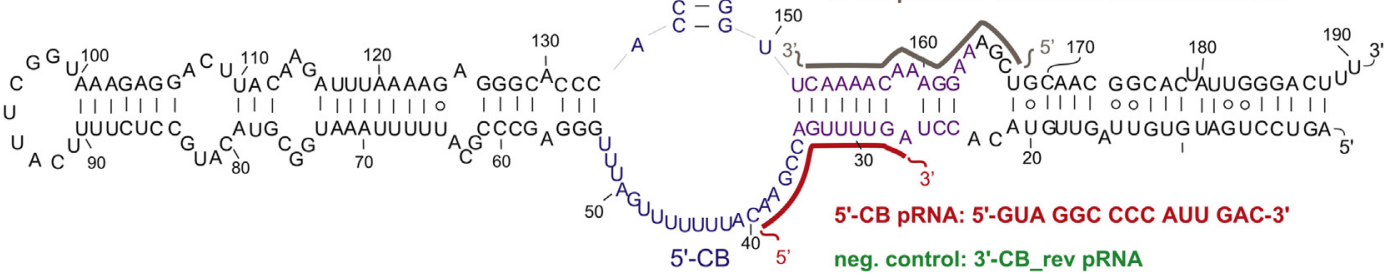

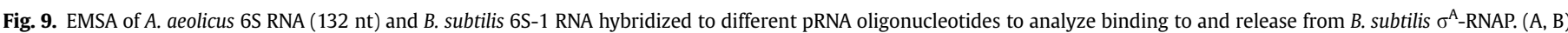

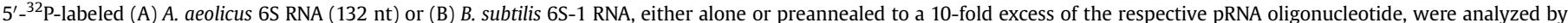

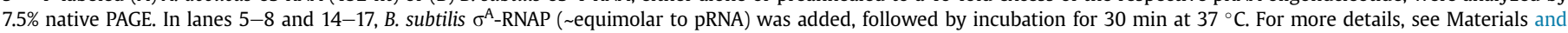

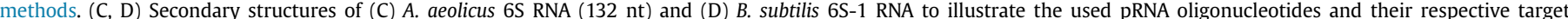

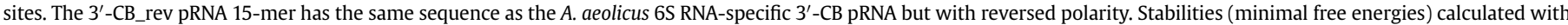

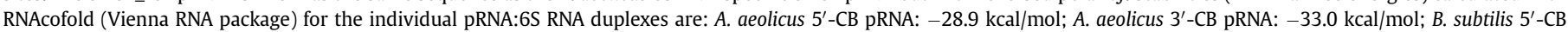
pRNA: $-20.3 \mathrm{kcal} / \mathrm{mol}$; B. subtilis 3'-CB pRNA: $-21.9 \mathrm{kcal} / \mathrm{mol}$.

evolutionarily optimized for transcriptional pRNA initiation in the $5^{\prime}-\mathrm{CB}$.

\section{Materials and Methods}

\section{1. $6 S$ RNA variants and pRNA mimics}

6S RNAs were in vitro transcribed by T7 RNA polymerase from linearized plasmids as described $[2,4]$. The 85 -nt and 132-nt variants of $A$. aeolicus 6S RNA were transcribed from pUC19 derivatives
pKK4 and pKK5, respectively, essentially as described [8]. Both plasmids encoded the T7 promoter, a self-cleaving hammerhead cassette, the respective A. aeolicus 6S RNA variant and a selfcleaving hepatitis delta virus (HDV) ribozyme. The ribozymes self-cleaved during T7 transcription and the mature 85-nt and 132nt 6S RNA transcripts with homogenous $5^{\prime}$ - and $3^{\prime}$-ends were purified by denaturing PAGE. For probing experiments in Figs. $4 \mathrm{~B}$ and 5B, the 132-nt 6S RNA variant was transcribed from plasmid pKK8 encoding the RNA with a $3^{\prime}$-terminal mismatch $\left(3^{\prime}\right.$-terminal $\mathrm{C}$ to $\mathrm{A}$ mutation) to improve $3^{\prime}$-end-labeling using $5^{\prime}-\left[{ }^{32} \mathrm{P}\right] \mathrm{PC}$. Synthetic 
pRNA oligonucleotides were obtained from Integrated DNA technologies (IDT, Coralville, Iowa, USA). The all-LNA analog of the pRNA 15-mer was synthesized by RiboTask (Denmark). ${ }^{15} \mathrm{~N}$-labeled nucleotides for the synthesis of isotope-labeled RNAs for NMR measurements were purchased from Silantes (Munich, Germany).

\subsection{Secondary structure probing}

For probing experiments, trace amounts of $5^{\prime}$ - or $3^{\prime}$-endlabeled 6S RNA ( 30,000 Cherenkov cpm) were mixed with the same unlabeled 6S RNA to a final concentration of $9 \mu \mathrm{M}$ in $1.25 \times$ TN-buffer pH 7.5 (20 mM Tris-acetate, $100 \mathrm{mM} \mathrm{NaCl}$ ) in a volume of $4 \mu \mathrm{L}$. For determination of the 6S RNA structure in its pRNA-bound state, a $\sim 5$-fold excess of the pRNA oligonucleotide was added (f.c. $50 \mu \mathrm{M}$; vol. $4 \mu \mathrm{L}$ ). All samples were denatured for $1 \mathrm{~min}$ at $95{ }^{\circ} \mathrm{C}$ and immediately transferred to and kept at $2{ }^{\circ} \mathrm{C}$ for $2 \mathrm{~min}$; refolding and pRNA annealing was achieved by slowly raising the temperature from 2 to $22^{\circ} \mathrm{C}$ within $5 \mathrm{~min}$. For RNase T1 cleavage reactions, $1 \mu \mathrm{L}$ RNase T1 ( $1 \mathrm{U})$ was added to $4 \mu \mathrm{L}$ of RNA solution in the case of the $132-n t$ variant or $1 \mu \mathrm{L}$ RNase T1 (0.1 U) in case of the 6S RNA 85-nt variant, followed by incubation at room temperature for $0.5 \mathrm{~min}$ (132-nt variant) or $4 \mathrm{~min}$ (85-nt variant) and addition of $5 \mu \mathrm{L}$ denaturing loading buffer $(0.02 \%[\mathrm{w} / \mathrm{v}]$ bromophenol blue, $0.02 \%$ $[\mathrm{w} / \mathrm{v}]$ xylene cyanol blue, $2.6 \mathrm{M}$ urea, $66 \%[\mathrm{v} / \mathrm{v}]$ formamide, $2 \times \mathrm{TBE}$ buffer, $\mathrm{pH}$ 8.0). To generate an RNase T1 ladder, $4 \mu \mathrm{L}$ of the corresponding RNA solution was preheated to $55{ }^{\circ} \mathrm{C}$ for $5 \mathrm{~min}$ and incubated with $1 \mathrm{U}$ (132-nt variant) or $0.1 \mathrm{U}$ (85-nt variant) RNase $\mathrm{T} 1$ for 1 or $2 \mathrm{~min}$, respectively, in $1 \times \mathrm{TN}$-buffer at $55{ }^{\circ} \mathrm{C}$. For lead cleavage, $4 \mu \mathrm{L}$ RNA solution were mixed with $1 \mu \mathrm{L}$ freshly prepared $2 \mathrm{mM} \mathrm{Pb}(\mathrm{OAc})_{2}$ (f.c. $0.4 \mathrm{mM}$ ), followed by incubation for $6 \mathrm{~min}$ (6S RNA 132-nt) or 4 min (6S RNA 85-nt) at room temperature. For lead hydrolysis of the $6 \mathrm{~S}$ RNA 132 -nt variant at $37{ }^{\circ} \mathrm{C}$ and $55^{\circ} \mathrm{C}$, the incubation time was shortened to $4 \mathrm{~min}\left(37^{\circ} \mathrm{C}\right)$ and $1 \min \left(55^{\circ} \mathrm{C}\right)$. At $75{ }^{\circ} \mathrm{C}, 1 \mu \mathrm{L}$ of $0.5 \mathrm{mM} \mathrm{Pb}(\mathrm{OAc}) 2$ was added to $4 \mu \mathrm{L}$ of RNA solution, followed by incubation for $1 \mathrm{~min}$ before addition of denaturing loading buffer. For RNase V1 cleavage, $0.01 \mathrm{U}(0.001 \mathrm{U})$ RNase V1 were added to the 132-nt (85-nt) RNA, followed by adjustment to $\sim 6 \mu \mathrm{M} \mathrm{Mg}^{2+}$ and incubation $1 \mathrm{~min}(0.5 \mathrm{~min})$ at room temperature. To generate an alkaline ladder, labeled and unlabeled RNA were mixed $(\sim 1.5 \mu \mathrm{g})$ in alkaline buffer $\left(0.1 \mathrm{M} \mathrm{Na}_{2} \mathrm{CO}_{3} / 0.1 \mathrm{M}\right.$ $\mathrm{NaHCO}_{3} \mathrm{pH} 9.0$; final vol. $5 \mu \mathrm{L}$ ) and heated to $95{ }^{\circ} \mathrm{C}$ for $1 \mathrm{~min}$, followed by addition of 1 vol. denaturing loading buffer to stop the reaction. Samples were separated on a $15 \%$ or $20 \%$ denaturing PAA gels. After electrophoresis, gels were transferred onto a Whatman filter paper ( $2 \mathrm{~mm}$ thick), covered with clingfilm and dried in a vacuum gel drier at $60^{\circ} \mathrm{C}$ for $1 \mathrm{~h}$. An image plate was exposed to the gel overnight. Radioactive RNA fragments were visualized using a Bio-Imaging Analyzer FLA 3000-2R (Fujifilm) and the analysis software PCBAS/AIDA (Raytest).

\subsection{NMR experiments}

NMR spectra were recorded at a $950 \mathrm{MHz}$, a $900 \mathrm{MHz}$ or a $800 \mathrm{MHz}$ Bruker NMR spectrometer equipped with cryogenic triple resonance probes using the Topspin software for acquisition and data processing. NMR samples of the 132-nt and the 85-nt 6S RNA variant were concentrated to a final volume of around $250 \mu \mathrm{L}$ using micoconcentrators (cutoff $3.000 \mathrm{Da}$, Vivaspin) and $10 \%(\mathrm{v} / \mathrm{v}) \mathrm{D}_{2} \mathrm{O}$ was added. The final concentrations were 506 and $187 \mu \mathrm{M}$ for the unlabeled and the ${ }^{15} \mathrm{~N}$ uridine- and guanine-labeled 132 -nt variant, respectively, and 864 and $143 \mu \mathrm{M}$ for the unlabeled and the ${ }^{15} \mathrm{~N}$ uridine- and guanine-labeled 85-nt variant, respectively. For the unlabeled samples, ${ }^{1} \mathrm{H},{ }_{1}^{1} \mathrm{H}$ NOESY spectra using a Watergate water suppression scheme were acquired for the free RNA and the RNA hybridized to a 15 -nt pRNA. For the ${ }^{15} \mathrm{~N}$-labeled samples, ${ }^{1} \mathrm{H},{ }^{15} \mathrm{~N}$
HSQC spectra using a Watergate water suppression scheme were recorded for the free RNA and the RNA hybridized to a 15-nt pLNA (132-nt variant) or a 15-nt pRNA (85-nt variant). For pR(L)NA annealing, a 10-fold molar excess of $\mathrm{pR}(\mathrm{L}) \mathrm{NA}$ was incubated with $6 \mathrm{~S}$ RNA as described in Section 3.7. Excess pR(L)NA was removed by four filter washes through Amicon ${ }^{\mathbb{B}}$ Ultra $0.5 \mathrm{~mL}$ centrifugal filters (30 kDa cutoff for the 132-nt 6S RNA and $10 \mathrm{kDa}$ cutoff for the 85-nt 6S RNA variant), using $500 \mu \mathrm{L} 1 \times$ hybridization buffer $(25 \mathrm{mM}$ $\mathrm{KHPO}_{4}, \mathrm{pH}$ 6.2, $50 \mathrm{mM} \mathrm{KCl}, 100 \mathrm{mM} \mathrm{NH}_{4} \mathrm{Cl}$ ) for each wash step. 6S RNA samples were then concentrated as described above. For the 132-nt variant, all experiments were carried out at a temperature of $20^{\circ} \mathrm{C}$, where the ${ }^{1} \mathrm{H},{ }^{15} \mathrm{~N}$ HSQC spectra showed most uniform signal intensities. The ${ }^{1} \mathrm{H},{ }^{1} \mathrm{H}$ NOESY spectrum of the free unlabeled 132-nt RNA was recorded on the $900 \mathrm{MHz}$ spectrometer; the ${ }^{1} \mathrm{H},{ }_{1}^{1} \mathrm{H}$ NOESY spectrum of the 132-nt RNA/pRNA complex and the ${ }^{1} \mathrm{H},{ }^{15} \mathrm{~N}$ HSQC spectra of the ${ }^{15} \mathrm{~N}$-labeled free RNA as well as its complex with the pLNA 15-mer were recorded on the $950 \mathrm{MHz}$ spectrometer. For the 85-nt variant, the ${ }^{1} \mathrm{H},{ }^{15} \mathrm{~N}$ HSQC spectra were recorded at $20^{\circ} \mathrm{C}$ on the $800 \mathrm{MHz}$ spectrometer. The ${ }^{1} \mathrm{H},{ }^{1} \mathrm{H}$ NOESY spectra obtained at $20{ }^{\circ} \mathrm{C}$ on the $950 \mathrm{MHz}$ spectrometer showed only very low NOE cross peak intensities. The NOESY spectrum of the 85-nt RNA/pRNA complex was therefore also recorded at $10{ }^{\circ} \mathrm{C}$ providing increased signal intensities.

\subsection{RNA-seq of A. aeolicus}

A. aeolicus cells were grown at $85{ }^{\circ} \mathrm{C}$ and harvested in late exponential growth phase (approximate cell density: $2 \times 10^{8}$ cells/ $\mathrm{mL}$, approx. $0.2 \mathrm{OD}_{600} / \mathrm{mL}$ ) as described [9] and total RNA was extracted basically as previously reported [2]. In detail, lyophilized cell pellets (corresponding to $\sim 8 \mathrm{OD}_{600}$ ) were resuspended in $4 \mathrm{~mL}$ of pre-chilled $\left(4^{\circ} \mathrm{C}\right)$ extraction buffer ( $10 \mathrm{mM} \mathrm{NaOAc}, 150 \mathrm{mM}$ sucrose, $\mathrm{pH} 4.8$ ). Then, $200 \mu \mathrm{L}$ of $20 \%$ SDS was added and the suspension was mixed with $4 \mathrm{~mL}$ preheated $\left(65^{\circ} \mathrm{C}\right)$ acidic phenol $(\mathrm{pH}$ 4.5 to 5.0 , Roth, Germany) followed by vigorous vortexing, incubation for $5 \mathrm{~min}$ at $65{ }^{\circ} \mathrm{C}$ and then $5 \mathrm{~min}$ on ice. For phase separation, the mixture was centrifuged at $\sim 12,900 \mathrm{~g}$ for $20 \mathrm{~min}$ at $4{ }^{\circ} \mathrm{C}$. The aqueous supernatant was transferred to a fresh tube and again $4 \mathrm{~mL}$ acidic phenol were added, followed by vigorous mixing. After an identical centrifugation step, the supernatant was transferred to a new tube and mixed with $4 \mathrm{~mL}$ chloroform by vortexing. After centrifugation at room temperature, the supernatant was transferred to a clean tube, and 0.1 vol. $3 \mathrm{M} \mathrm{NaOAc}$ (pH 5) and 1 vol. of isopropanol were added, followed by centrifugation at $\sim 12,900 \mathrm{~g}$ for $45 \mathrm{~min}$ at $4{ }^{\circ} \mathrm{C}$. The RNA pellet was washed with $200 \mu \mathrm{L} 70 \%$ ethanol, centrifuged for $15 \mathrm{~min}\left(\sim 12,900 \mathrm{~g}, 4^{\circ} \mathrm{C}\right)$ and air-dried for $5 \mathrm{~min}$. The pellet was redissolved in $65 \mu \mathrm{L} \mathrm{ddH}_{2} \mathrm{O}$ containing $\sim 3.5-5 \mu \mathrm{g} / \mu \mathrm{L}$ RNA.

We performed two deep sequencing experiments: one applying 454 high-throughput sequencing as described [9] without any size fractionation of the total RNA; and a second one applying Illumina sequencing technology, where the total RNA was purified via the mirVana isolation kit (Ambion) to enrich for RNAs $<200 \mathrm{nt}$, followed by isolation of RNAs $<50$ nt using preparative $10 \%$ denaturing PAGE. In both experiments, RNA fractions were further enriched for primary transcripts by Terminator ${ }^{\mathrm{TM}} 5^{\prime}$-PhosphateDependent Exonuclease (TEX) treatment [2]; for the 454 sequencing experiment, libraries with and without TEX treatment were constructed and sequenced. Illumina reads were trimmed to a minimum quality threshold value of 20 using the fastx-toolkit. $\operatorname{Poly}(\mathrm{A})$-tails of length five and longer were removed from the Illumina and 454 reads. Both read libraries were mapped to the genome of $A$. aeolicus VF5 (NCBI uid: 57765) using segemehl. Mapped reads had to be at least $8 \mathrm{nt}$ long, with an $80 \%$ sequence match to the target region. We tracked alternative mappings to 
exclude a bias due to non-6S RNA derived reads that mapped multiple times to the A. aeolicus genome (see Fig. S1).

\subsection{In vitro $p R N A$ transcription}

A mixture of $1 \mu \mathrm{L}$ A. aeolicus $6 \mathrm{~S}$ RNA (132 nt, $10 \mu \mathrm{M})$ and $1 \mu \mathrm{L} 2 \times$ TE buffer (10 mM Tris-HCl, $1 \mathrm{mM}$ EDTA, pH 8 ) was heated to $80^{\circ} \mathrm{C}$ (2 min) and stepwise cooled down to $70^{\circ} \mathrm{C}, 60^{\circ} \mathrm{C}$ and $50{ }^{\circ} \mathrm{C}(2 \mathrm{~min}$ each), followed by a final incubation step at $37^{\circ} \mathrm{C}$ for $2 \mathrm{~min}$. Then, $\sim 4.7 \mu \mathrm{L}$ master mix including activity buffer and B. subtilis $\sigma^{\mathrm{A}}$-RNAP holoenzyme $(8 \mathrm{mg} / \mathrm{mL})$, prepared as described in Ref. [15] were added to the RNA solution, followed by incubation at $37^{\circ} \mathrm{C}$ for $10 \mathrm{~min}$. The transcription reaction was started by adding $200 \mu \mathrm{M}$ of each NTP (f.c.), including $\sim 250,000$ Cherenkov cpm of either $\alpha_{-}{ }^{32} \mathrm{P}-$ UTP, $\alpha-{ }^{32} \mathrm{P}-\mathrm{CTP}$ or $\gamma-{ }^{32} \mathrm{P}-\mathrm{GTP}$. The final reaction volume of $10 \mu \mathrm{L}$ contained $1 \mu \mathrm{M}$ 6S RNA, $1 \mu \mathrm{M} \sigma^{\mathrm{A}}$-RNAP and $1 \times$ activity buffer (40 mM Tris- $\mathrm{HCl}, \mathrm{pH} 8.0,5 \mathrm{mM} \mathrm{MgCl}, 160 \mathrm{mM} \mathrm{KCl}, 1 \mathrm{mM}$ DTT). After incubation at $37{ }^{\circ} \mathrm{C}$ for $1 \mathrm{~h}, 5 \mu \mathrm{L}$ were withdrawn and mixed with $15 \mu \mathrm{L}$ highly denaturing loading buffer $[0.02 \%(\mathrm{w} / \mathrm{v})$ bromophenol blue, $0.02 \%(\mathrm{w} / \mathrm{v})$ xylene cyanol blue, $8 \mathrm{M}$ urea, $50 \%(\mathrm{v} / \mathrm{v})$ deionized formamide, $2 \times$ TBE, $\mathrm{pH}$ 8.0]. The samples were heated to $98{ }^{\circ} \mathrm{C}$ for $3 \mathrm{~min}$, incubated on ice for $20 \mathrm{~min}$ and loaded onto a $25 \%$ denaturing PAA gel $\left(1 \times\right.$ TBE). Two $55^{\prime}{ }^{32}$ P-endlabeled synthetic A. aeolicus pRNAs ( $8 \mathrm{nt}$ and $15 \mathrm{nt}$ ) were used as size markers.

\subsection{RNA-seq analysis after in vitro pRNA transcription}

For RNA-seq analysis, six in vitro pRNA transcription reactions as described above, but without radioactive nucleotides, were combined and extracted with acidic phenol, followed by chloroform extraction and ethanol precipitation. The pellet was dissolved in $5 \mu \mathrm{L} \mathrm{ddH}_{2} \mathrm{O}$ (114 ng/ $\mu \mathrm{L}$ ); cDNA libraries were constructed at vertis Biotechnologie AG (Freising, Germany) including TEX treatment to enrich for pRNAs carrying a 5'-triphosphate.

\section{7. pRNA:6S RNA annealing}

$9 \mathrm{pmol}$ A. aeolicus 6S RNA (85-nt or 132-nt variant) or B. subtilis 6S-1 RNA, containing trace amounts of the same $5^{\prime}-{ }^{32} \mathrm{P}$-endlabeled 6S RNA (10,000 Cherenkov cpm/lane), were mixed with 50 pmol (Figs. 3-5) or 100 pmol (Fig. 9) pRNA in $1 \times$ hybridization buffer (see Section 3.3) to a final volume of $20 \mu \mathrm{L}$. The mixture was heated to $95{ }^{\circ} \mathrm{C}$ for $5 \mathrm{~min}$ (85-nt variant) or $10 \mathrm{~min}$ (132-nt variant) in a $250-\mu \mathrm{L}$ PCR reaction tube using a thermocycler, followed by stepwise cooling ( $5{ }^{\circ} \mathrm{C}$ steps for $5 \mathrm{~min}$ each) to $37^{\circ} \mathrm{C}$. In negative controls, $\mathrm{ddH}_{2} \mathrm{O}$ was added instead of pRNA oligomers. After the annealing procedure, samples were supplemented with $20 \mu \mathrm{L}$ of $2 \times$ native loading buffer $(30 \%(\mathrm{v} / \mathrm{v})$ glycerol, $1 \%(\mathrm{w} / \mathrm{v})$ bromophenol blue, $1 \%(\mathrm{w} / \mathrm{v})$ xylene cyanol blue) and stored on ice until all samples were analyzed by $7.5 \%$ native PAGE at room temperature, or were further incubated with B. subtilis $\sigma^{\mathrm{A}}$-RNAP (Fig. 9A, B) before gel loading, as described in the following.

\subsection{Analysis of $6 S$ RNA:RNAP complexation}

6S RNAs (f.c. $0.24 \mu \mathrm{M}$, containing trace amounts of the same $5^{\prime}-{ }^{32} \mathrm{P}$-endlabeled 6S RNA), in the presence or absence of pRNA oligonucleotide (f.c. $2.4 \mu \mathrm{M}$ ), were incubated in $1 \times$ hybridization buffer (see above) at $95^{\circ} \mathrm{C}$ for $10 \mathrm{~min}$, followed by stepwise cooling to $37^{\circ} \mathrm{C}\left(90,80,70,60,50\right.$ and $40{ }^{\circ} \mathrm{C}$ each for $5 \mathrm{~min}$, and $10 \mathrm{~min}$ at $37^{\circ} \mathrm{C}$ ). Afterward, all samples were supplemented with $1 \times$ activity buffer (see above) and heparin (f.c. $8 \mathrm{ng} / \mu \mathrm{L}$ ) to suppress unspecific RNA-protein binding; then B. subtilis $\sigma^{A}$-RNAP (f.c. $2.2 \mu \mathrm{M}$ ) was added, and all samples (final vol. $8.5 \mu \mathrm{L}$ ) were incubated for $30 \mathrm{~min}$ at $37{ }^{\circ} \mathrm{C}$. Samples were then supplemented with 1 volume of $2 \times$ native loading buffer (see above) and loaded onto a $7.5 \%$ native PAA gel $(1 \times$ TBE as electrophoresis buffer).

\section{Conflict of interest}

The authors declare that there is no conflict of interest.

\section{Acknowledgments}

We would like to thank Dagmar K. Willkomm for construction of A. aeolicus 6S RNA expression plasmids and Jens Wöhnert for helpful discussions. This project was funded by the DFG (SPP 1258 and IRTG 1384) to RKH, by the DFG (SFB 902 A2) to EDF and the Spanish Ministry of Economy and Competitiveness (BFU201123645) to M.S.

\section{Appendix A. Supplementary data}

Supplementary data related to this article can be found at http:// dx.doi.org/10.1016/j.biochi.2015.03.004.

\section{References}

[1] J.E. Barrick, N. Sudarsan, Z. Weinberg, W.L. Ruzzo, R.R. Breaker, 6S RNA is a widespread regulator of eubacterial RNA polymerase that resembles an open promoter, RNA 11 (5)(2005) 774-784, http://dx.doi.org/10.1261/rna.7286705.

[2] B.M. Beckmann, O.Y. Burenina, P.G. Hoch, E.A. Kubareva, C.M. Sharma, R.K. Hartmann, In vivo and in vitro analysis of 6S RNA-templated short transcripts in Bacillus subtilis, RNA Biol. 8 (5) (2011) 839-849.

[3] B.M. Beckmann, P.G. Hoch, M. Marz, D.K. Willkomm, M. Salas, R.K. Hartmann, A pRNA-induced structural rearrangement triggers 6S-1 RNA release from RNA polymerase in Bacillus subtilis, EMBO J. 31 (7) (2012) 1727-1738.

[4] O.Y. Burenina, P.G. Hoch, K. Damm, M. Salas, T.S. Zatsepin, M. Lechner, T.S. Oretskaya, E.A. Kubareva, R.K. Hartmann, Mechanistic comparison of $\mathrm{Ba}$ cillus subtilis 6S-1 and 6S-2 RNAs-commonalities and differences, RNA 20 (3) (2014) 348-359, http://dx.doi.org/10.1261/rna.042077.113.

[5] I.J. Cabrera-Ostertag, A.T. Cavanagh, K.M. Wassarman, Initiating nucleotide identity determines efficiency of RNA synthesis from 6S RNA templates in Bacillus subtilis but not Escherichia coli, Nucleic Acids Res. 41 (15) (2013) 7501-7511, http://dx.doi.org/10.1093/nar/gkt517.

[6] A.T. Cavanagh, A.D. Klocko, X. Liu, K.M. Wassarman, Promoter specificity for 6S RNA regulation of transcription is determined by core promoter sequences and competition for region 4.2 of $\sigma^{70}$, Mol. Microbiol. 67 (6) (2008) 1242-1256, http://dx.doi.org/10.1111/j.1365-2958.2008.06117.x.

[7] G. Deckert, P.V. Warren, T. Gaasterland, W.G. Young, A.L. Lenox, D.E. Graham, R. Overbeek, M.A. Snead, M. Keller, M. Aujay, R. Huber, R.A. Feldman, J.M. Short, G.J. Olsen, R.V. Swanson, The complete genome of the hyperthermophilic bacterium Aquifex aeolicus, Nature 392 (6674) (1998) 353-358, http://dx.doi.org/10.1038/32831.

[8] J. Kondo, A.C. Dock-Bregeon, D.K. Willkomm, R.K. Hartmann, E. Westhof, Structure of an A-form RNA duplex obtained by degradation of 6S RNA in a crystallization droplet, Acta Crystallogr. F. 69 (6) (2013) 634-639, http:// dx.doi.org/10.1107/S1744309113013018.

[9] M. Lechner, A.I. Nickel, S. Wehner, K. Riege, N. Wieseke, B.M. Beckmann, R.K. Hartmann, M. Marz, Genomewide comparison and novel ncRNAs of Aquificales, BMC Genomics 15 (522) (2014), http://dx.doi.org/10.1186/14712164-15-522.

[10] R. Lorenz, S.H. Bernhart, C. Höner Zu Siederdissen, H. Tafer, C. Flamm, P.F. Stadler, I.L. Hofacker, ViennaRNA package 2.0, Algorithms Mol. Biol. 6 (26) (2011), http://dx.doi.org/10.1186/1748-7188-6-26.

[11] J.W. Nicol, G.A. Helt, S.G. Blanchard, A. Raja, A.E. Loraine, The Integrated Genome Browser: free software for distribution and exploration of genomescale datasets, Bioinformatics 25 (20) (2009) 2730-2731.

[12] S.S. Panchapakesan, P.J.E. Unrau, E. coli 6S RNA release from RNA polymerase requires $\sigma^{70}$ ejection by scrunching and is orchestrated by a conserved RNA hairpin, RNA 18 (2012) 2251-2259, http://dx.doi.org/10.1261/rna.034785.112.

[13] C.M. Sharma, S. Hoffmann, F. Darfeuille, J. Reignier, S. Findeiss, A. Sittka, S. Chabas, K. Reiche, J. Hackermüller, R. Reinhardt, P.F. Stadler, J. Vogel, The primary transcriptome of the major human pathogen Helicobacter pylori, Nature 464 (7286) (2010) 250-255, http://dx.doi.org/10.1038/nature08756.

[14] L. Shephard, N. Dobson, P.J. Unrau, Binding and release of the $6 \mathrm{~S}$ transcriptional control RNA, RNA 16 (5) (2010) 885-892, http://dx.doi.org/10.1261/ rna.2036210.

[15] J.M. Sogo, M.R. Inciarte, J. Corral, E. Viñuela, M. Salas, RNA polymerase binding sites and transcription map of the DNA of Bacillus subtilis phage $\Phi 29$, J. Mol. Biol. 127 (4) (1979) 411-436.

[16] B. Steuten, P.G. Hoch, K. Damm, S. Schneider, K. Köhler, R. Wagner, R.K. Hartmann, Regulation of transcription by 6S RNAs: insights from the 
Escherichia coli and Bacillus subtilis model systems, RNA Biol. 11 (5) (2014) 1-14, http://dx.doi.org/10.4161/rna.28827.

[17] B. Steuten, R. Wagner, A conformational switch is responsible for the reversal of the 6S RNA-dependent RNA polymerase inhibition in Escherichia coli, Biol. Chem. 393 (12) (2012) 1513-1522, http://dx.doi.org/10.1515/hsz-2012-0237.

[18] B. Steuten, P. Setny, M. Zacharias, R. Wagner, Mapping the spatial neighborhood of the regulatory 6S RNA bound to Escherichia coli RNA polymerase holoenzyme, J. Mol. Biol. 425 (19) (2013) 3649-3661, http://dx.doi.org/ 10.1016/j.jmb.2013.07.008.

[19] A.E. Trotochaud, K.M. Wassarman, A highly conserved 6S RNA structure is required for regulation of transcription, Nat. Struct. Biol. 188 (11) (2005) 3936-3943, http://dx.doi.org/10.1038/nsmb917.
[20] K.M. Wassarman, R.M. Saecker, Synthesis-mediated release of a small RNA inhibitor of RNA polymerase, Science 314 (5805) (2006) 1601-1603, http:/ dx.doi.org/10.1126/science.1134830.

[21] S. Wehner, K. Damm, R.K. Hartmann, M. Marz, Dissemination of 6S RNA among bacteria, RNA Biol. 11 (11) (2014) 1468-1479, http://dx.doi.org 10.4161/rna.29894 [Epub ahead of print].

[22] D.K. Willkomm, J. Minnerup, A. Hüttenhofer, R.K. Hartmann, Experimenta RNomics in Aquifex aeolicus: identification of small non-coding RNAs and the putative 6S RNA homolog, Nucleic Acids Res. 33 (6) (2005) 1949-1960, http:// dx.doi.org/10.1093/nar/gki334. 